Office of Radiation Protection

\title{
TECHNICAL BASIS FOR NUCLEAR ACCIDENT DOSIMETRY AT THE OAK RIDGE NATIONAL LABORATORY
}

\author{
George D. Kerr and Gloria T. Mei
}

Manuscript completed: June 1993

Date published: August 1993

NOTICE This document contains information of a preliminary nature. It is subject to revision or correction and therefore does not represent a final report.

Prepared by the

OAK RIDGE NATIONAL LABORATORY

Oak Ridge, Tennessee 37831-6285 managed by

MARTIN MARIETTA ENERGY SYSTEMS, INC.

for the

U.S. DEPARTMENT OF ENERGY under contract DE-AC05-84OR21400 


\section{TABLE OF CONTENTS}

Page

ABSTRACT $\ldots \ldots \ldots \ldots \ldots \ldots \ldots \ldots \ldots \ldots \ldots \ldots \ldots$

1. INTRODUCTION $\ldots \ldots \ldots \ldots \ldots \ldots \ldots \ldots \ldots \ldots \ldots \ldots$

2. REGULATORY GUIDELINES $\ldots \ldots \ldots \ldots \ldots \ldots \ldots \ldots \ldots \ldots$

3. ORNL NUCLEAR ACCIDENT DOSIMETER COMPONENTS $\ldots \ldots \ldots \ldots \ldots$. 3

3.1 QUICK SORT TECHNIQUE $\ldots \ldots \ldots \ldots \ldots \ldots \ldots \ldots \ldots$

3.2 BLOOD SODIUM ACTIVATION $\ldots \ldots \ldots \ldots \ldots \ldots \ldots$

3.3 HAIR SULFUR ACTIVATION $\ldots \ldots \ldots \ldots \ldots \ldots \ldots \ldots$

3.4 PERSONNEL NUCLEAR ACCIDENT DOSIMETERS $\ldots \ldots \ldots \ldots 28$

3.5 FIXED NUCLEAR ACCIDENT DOSIMETERS $\ldots \ldots \ldots \ldots \ldots$

4. NUCLEAR ACCIDENT DOSE ASSESSMENT $\ldots \ldots \ldots \ldots \ldots \ldots \ldots$

5. CONCLUSIONS $\ldots \ldots \ldots \ldots \ldots \ldots \ldots \ldots \ldots \ldots \ldots \ldots \ldots \ldots \ldots \ldots$

6. REFERENCES $\ldots \ldots \ldots \ldots \ldots \ldots \ldots \ldots \ldots \ldots \ldots \ldots \ldots \ldots \ldots \ldots \ldots \ldots$ 


\section{LIST OF FIGURES}

Eigure

Page

1 Photograph of the security badge and personnel dosimeters used at Oak Ridge National Laboratory $\ldots \ldots \ldots \ldots \ldots \ldots \ldots$

2 Placement of open side-window probe of a Geiger-Mueller Survey Meter for direct reading of the indium foil in a security badge $\ldots \ldots \ldots \ldots$

3 Action levels versus indium-foil readings with a Geiger-Mueller Survey Meter $\ldots \ldots \ldots \ldots \ldots \ldots \ldots \ldots \ldots \ldots \ldots \ldots$

4 Calibration data for a $15-\mathrm{mL}$ sample centered on the top surface of the cylindrical $168-\mathrm{cm}^{3}$ germanium detector $\ldots \ldots \ldots \ldots \ldots$

5 Neutron capture probability for neutrons incident on the front body surface of a realistic man-type analogue or so-called

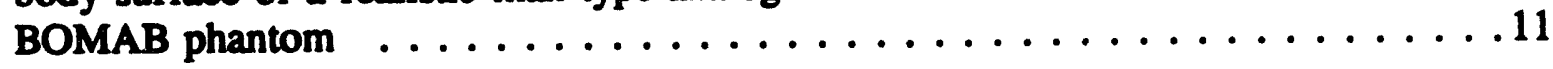

6 Neutron recoil-ion and capture gamma-ray components of absorbed dose from neutrons at the surface of the body facing the source $\ldots \ldots \ldots \ldots$

7 Illustration of the cross section of the ${ }^{32} S(n, p)^{32} \mathrm{P}$ reaction as a function of neutron energy $\ldots \ldots \ldots \ldots \ldots$

8 Plot of factors for obtaining $D$ (absorbed dose from neutrons) using data on $A_{N a}$ (specific activity of ${ }^{24} \mathrm{Na}$ in blood serum) and $A^{\text {Hair }}$

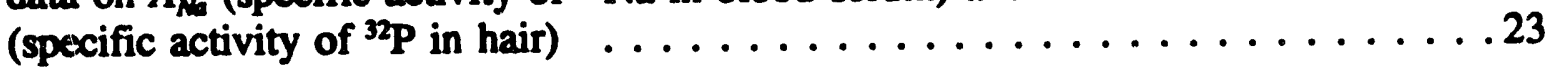

9 Plot of data on $D / A_{N a}$ versus $A_{H a r} / A_{N a}$ for spectra of fission neutrons

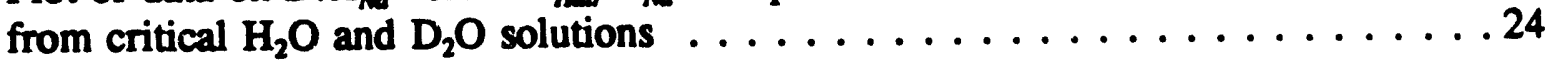

10 Plots of data on $D / A_{N a}$ versus $A_{H a r d} / A_{N e}$ for spectra of fission neutrons through shielding materials or reflectors of $\mathrm{H}_{2} \mathrm{O}, \mathrm{D}_{2} \mathrm{O}$, graphite, polyethylene, borated polyethylene, beryllium, and aluminum $\ldots \ldots \ldots \ldots \ldots$

11 Plots of data on $D / A_{N^{k}}$ versus $A_{\text {Hear }} / A_{N_{a}}$ for spectra of fission neutrons through shielding materials or reflectors of concrete, concrete with iron, iron, copper, lead, and depleted uranium $\ldots \ldots \ldots \ldots \ldots$ 


\section{LIST OF FIGURES \\ (continued)}

Eigure

Page

12 Plots of data on $D / A_{N_{a}}$ versus $A_{\text {Hara }} / A_{N_{a}}$ for spectra of moderated $\mathrm{H}_{2} \mathrm{O}$ fission neutrons through shielding materials or reflectors of beryllium, aluminum, concrete, iron, copper, and lead $\ldots \ldots \ldots \ldots \ldots$

13 Diagram of blue $\beta-\gamma$ dosimeter showing location of thermoluminescent detectors . . ..........................29

14 Diagram of red $\beta-\gamma$ dosimeter showing location of thermoluminescent

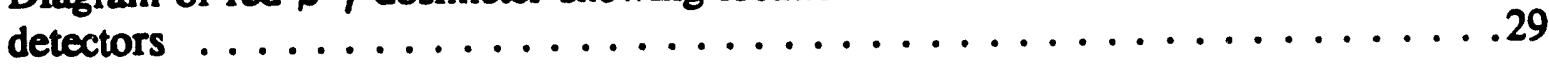

15 Absorbed dose from gamma rays at the front surface of the body for a person facing the source and a person facing away from the source $\ldots \ldots \ldots 31$

16 Photograph showing a FNAD which consists of two personnel dosimeters mounted on a small $20 \times 20 \times 10 \mathrm{~cm}$ phantom $\ldots \ldots \ldots \ldots \ldots \ldots \ldots \ldots$

17 Response of blue $\beta-\gamma$ dosimeter to high-level radiation from a ${ }^{137} \mathrm{Cs}$ ganma-ray source .38

18 Response of red neutron dosimeter to high-level radiation from a ${ }^{252} \mathrm{Cf}$ neutron source with no shielding $\ldots \ldots \ldots \ldots \ldots \ldots \ldots \ldots \ldots \ldots$

19 Response of red neutron dosimeter to high-level radiation from a ${ }^{137} \mathrm{Cs}$ gamma-ray source $\ldots \ldots \ldots \ldots \ldots \ldots \ldots \ldots \ldots \ldots \ldots \ldots \ldots \ldots \ldots$ 


\section{LIST OF TABLES}

Table

Page

1 Factors for converting specific activity of blood serum to absorbed dose at surface of body facing toward the source $\ldots \ldots \ldots \ldots \ldots \ldots$

2 Ratios of the specific activity of sulfur in hair to the specific activity of blood serum ........................20

3 Spectral correction factor for matched TLD-600/TLD-700 pairs with and without cadmium covers . . . . . . . . . . . . . . . 35

4 Summary of the $\beta-\gamma$ dosimeter tests at the Aberdeen Reactor $\ldots \ldots \ldots \ldots 2$

5 Summary of neutron dosimeter tests at Aberdeen Reactor $\ldots \ldots \ldots 43$

6 Dosimetric investigation of the Recuplex criticality accident $\ldots \ldots \ldots \ldots$ 


\title{
TECHNICAL BASIS FOR NUCLEAR ACCIDENT DOSIMETRY AT THE OAK RIDGE NATIONAL LABORATORY
}

\author{
George D. Kerr" and Gloria T. Mei
}

\begin{abstract}
The Oak Ridge National Laboratory (ORNL) Environmental, Safety, and Health Emergency Response Organization has the responsibility of providing analyses of personnel exposures to neutrons and gamma rays from a nuclear accident. This report presents the technical and philosophical basis for the dose assessment aspects of the nuclear accident dosimetry (NAD) system at ORNL. The issues addressed are regulatory guidelines, ORNL NAD system components and performance, and the interpretation of dosimetric information that would be gathered following a nuclear accident.
\end{abstract}

\section{INTRODUCTION}

The ORNL Environmental, Safety, and Health Emergency Response Organization has the responsibility of providing analyses of personnel exposures to neutrons and gamma rays from a nuclear accident. A nuclear accident is defined here as an unplanned and uncontrolled reaction in a critical mass of fissile materials.

Procedures and techniques for preventing nuclear accidents have reached very high standards, but the occurrence of a nuclear accident cannot be disregarded entirely. The individuals involved in a nuclear accident may be exposed to both neutrons and gamma rays from trivial to lethal levels. The principal concern is for a person who has received an absorbed dose to the whole body or to a major part thereof in excess of $0.25 \mathrm{~Gy}(25 \mathrm{rad})$. The use of equivalent dose ( $\mathrm{Sv}$ or rem) is not appropriate at the high doses and dose rates of most concern in a nuclear accident, because a quality factor for acute effects of neutrons has not been established (and it is probably between 1 and 3).

'Health Sciences Research Division, Oak Ridge National Laboratory, Oak Ridge, Tennessee. 
A nuclear accident dosimetry system should incorporate features that will allow the rapid identification of personnel exposures in descending order from most-to-least severe. This initial assessment is needed to: (1) prevent unnecessary overloading of medical facilities by lightly exposed individuals; (2) provide reassurance to individuals who have received small or negligible radiation doses; and (3) provide an immediate indication of the seriousness of the nuclear accident to management.

This report is intended to provide a technical and philosophical discussion of the dose assessment aspects of the ORNL NAD system. This system provides a rapid identification method and estimates of the total gamma-ray and neutron dose using several different techniques. Through this comprehensive program, the adequacy of the nuclear accident dose assessments are validated, thus ensuring that regulatory guidelines are met.

\section{REGULATORY GUIDELINES}

The first standard for nuclear accident dosimetry was issued in 1969 by the American National Standards Institute (ANSI) and was reaffirmed by ANSI in 1988 (ref. 1). This ANSI document calls for a lower limit of detection of $100 \mathrm{mGy}$ (10 rad), a neutron and gamma-ray dose accuracy of $\pm 25 \%$, and a rapid identification method or "quick-sort" technique to distinguish persons who received more than $100 \mathrm{mGy}(10 \mathrm{rad})$ from those who received less.

The guidance provided by the International Atomic Energy Agency (IAEA) is essentially the same as that presented above. ${ }^{2}$ This guidance advocates a quick-sort technique, a lower limit of $100 \mathrm{mGy}(10 \mathrm{rad})$, and an accuracy of $\pm 25 \%$. The IAEA suggests that the maxin :m possible accuracy is needed for dose measurements from $2 \mathrm{~Gy}(200 \mathrm{rad})$ to $8 \mathrm{~Gy}(800 \mathrm{rad})$ where lethality is possible but uncertain.

The regulatory requirements of the U.S. Department of Energy (DOE) are spelled out in DOE Order 5480.11, "Radiacion Protection for Occupational Workers. ${ }^{\text {"3 }}$ This DOE Order requires a quick-sort technique, a lower detection limit of $10 \mathrm{mGy}(1 \mathrm{rad})$ for neutrons and $100 \mathrm{mGy}(10 \mathrm{rad})$ for gamma rays, and a dose accuracy of $\pm 20 \%$ for gamma rays and $\pm 30 \%$ for neutrons. The upper range for dose measurements is set at approximately $10 \mathrm{~Gy}(1000 \mathrm{rad})$ for both neutrons and gamma rays. 


\section{ORNL NUCLEAR ACCIDENT DOSIMETER COMPONENTS}

The ORNL NAD system provides a quick-sort technique using an indium foil and estimates of the total neutron and gamma-ray dose using several different techniques. These latter techniques include: (1) personnel dosimeters, (2) facilities for analysis of neutron activation of sodium in blood and sulfur in hair, and (3) area dosimeter units capable of providing information such as neutron spectra or the ratio of the neutron dose to the gamma-ray dose at fixed locations. Chromosome aberration studies will also be conducted at the Radiation Emergency Assistance Center/Training Site (REAC/TS) of the Oak Ridge Institute for Science and Education (ORISE).

The ORNL personnel dosimeters consist of a blue $\beta-\gamma$ dosimeter for beta particles and gamma-rays (and screening of neutrons) and a red neutron dosimeter for neutrons as shown in Fig. 1. The blue $\beta-\gamma$ dosimeter is issued to all employees, while the red neutron dosimeter is issued only to persons who are exposed to neutrons sources. Only the blue $\beta-\gamma$ dosimeter is necessary to evaluate an accident-level dose. However, additional useful information may be derived from the neutron dosimeter or any other personnel inonitoring device that may be assigned to the exposed individual.

The absorbed dose from neutrons will also be evaluated using neutron activation of sodium in the body, particularly blood serum, ${ }^{4}$ and information on the orientation of the person will be obtained using neutron activation of sulfur in hair samples. ${ }^{2}$ Orientation is particularly important in assessing the neutron dose from blood sodium-activation measurements. For a fast neutron spectrum, the sodium activation can vary by more than $50 \%$, depending on whether the neutrons were incident on a person's front (or back) or side, although this effect may be reduced to $20 \%$ in a highly thermalized-neutron spectrum. ${ }^{2}$ It is essential, therefore, to question each person closely as to their position and movements during the accident and to compare the neutron activation ratios of sulfur and sodium for all persons involved in the accident. 


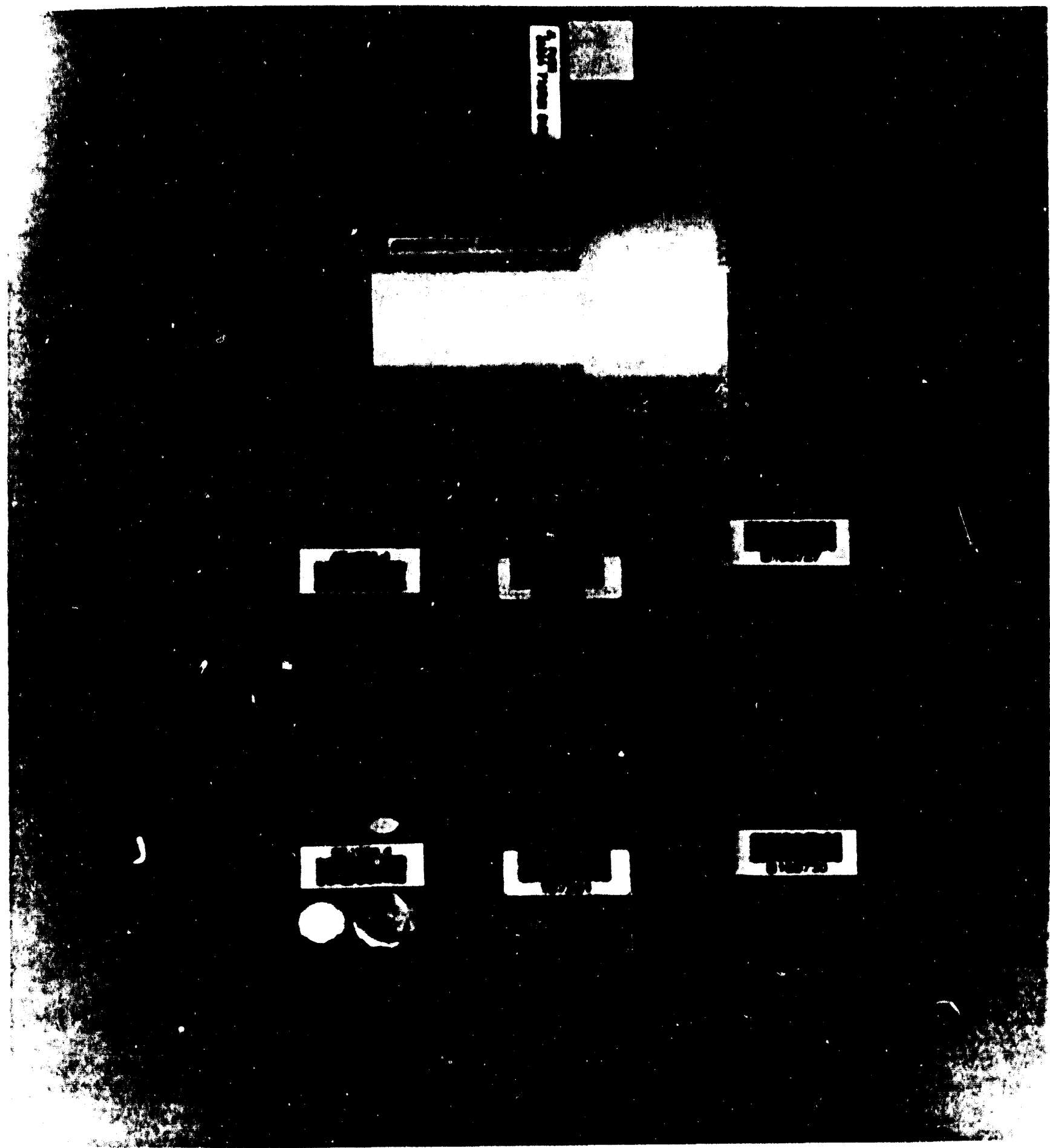

Fig. 1. Photograph of the security badge and personnel dosimeters used at Oak Ridge National Laboratory. Shown from top to bottom are: (1) a security badge with a blue $\beta-\gamma$ dosimeter attached; (2) a red neutron dosimeter which has been opened; (3) a blue $\beta-\gamma$ dosimeter which has also been opened; and (4) the tool used to open the personnel dosimeters. The red neutron dosimeter for neutrons and gamma rays is wom on a belt at the waist, and the blue $\beta-\gamma$ dosimeter is attached to the strap of the security badge which is worn on the shoulder or chest regions of the body. 


\subsection{QUICK-SORT TECHNIQUE}

The security badge, the blue $\beta-\gamma$ dosimeter, and the red neutron dosimeter (if worn) should be removed from each potentially exposed or contaminated person, and the location of the security badge and each dosimeter on the person's body should be recorded. An indium foil is located in the upper left-hand comer of the security badge under the words "Martin" and "Energy" of the logo for Martin Marietta Energy Systems, and the count rate of the indium foil should be determined by placement of a Geiger-Mueller Survey Meter (GMSM) as illustrated in Fig. 2 (ref. 5). This determination can be made by use of a GMSM having an Eberline Instrument Corporation Pancake GM Probe (Model HP-260), a Bicron Corporation Pancake GM Probe (Model PGM), or a Bicron Corporation Side-Window GM Probe (Model SWGM). The measured activity is due mainly to $\beta-\gamma$ decays of ${ }^{116}$ In (54-min half-life), which is produced by thermal neutron capture in "IsIn, and "115-In (4.5-h half-life), which is produced by fast neutron inelastic scattering reactions. ${ }^{\circ}$ Thus, the side window cover of the Bicron SWGM Probe should be opened for maximum sensitivity, and the count rate (minus background) from any of the three probes should be compared with those shown in Fig. 3. A count rate of the indium foil is taken to represent a probable high exposure if it is above Action Level II (estimated dose greater than $0.25 \mathrm{~Gy}$ ), an intermediate exposure if it is between Action Levels I and II (estimated dose less than $0.25 \mathrm{~Gy}$, but more than $0.02 \mathrm{~Gy}$ ), and a probable low exposure if it is below Action Level I (estimated dose less than $0.02 \mathrm{~Gy}$ ).

Activation of the indium foil may vary by a factor of as much as 10 depending on whether the individual was facing toward the source or away from the source at time of exposure. Hence, if an individual is classified as having a probabie intermediate or low exposure, it is important to make a second quick-sort measurement of the neutron activation of the person's body (after decontamination, if necessary) by placing the Bicron SWGM Probe against the abdominal area. The side window cover should be opened and the person should bend over the probe to increase the sensitivity of the measurements. ${ }^{6}$ The measured body activity is due primarily to $\beta-\gamma$ decays of ${ }^{38} \mathrm{Cl}\left(37-\mathrm{min}\right.$ half-life) and ${ }^{24} \mathrm{Na}(15-\mathrm{h}$ half-life), which are produced by the neutron capture in ${ }^{37} \mathrm{Cl}$ and ${ }^{23} \mathrm{Na}$ of the body, respectively. The radioactive decay is negligible over post exposure times of less than several hours because of the long ${ }^{24} \mathrm{Na}$ 


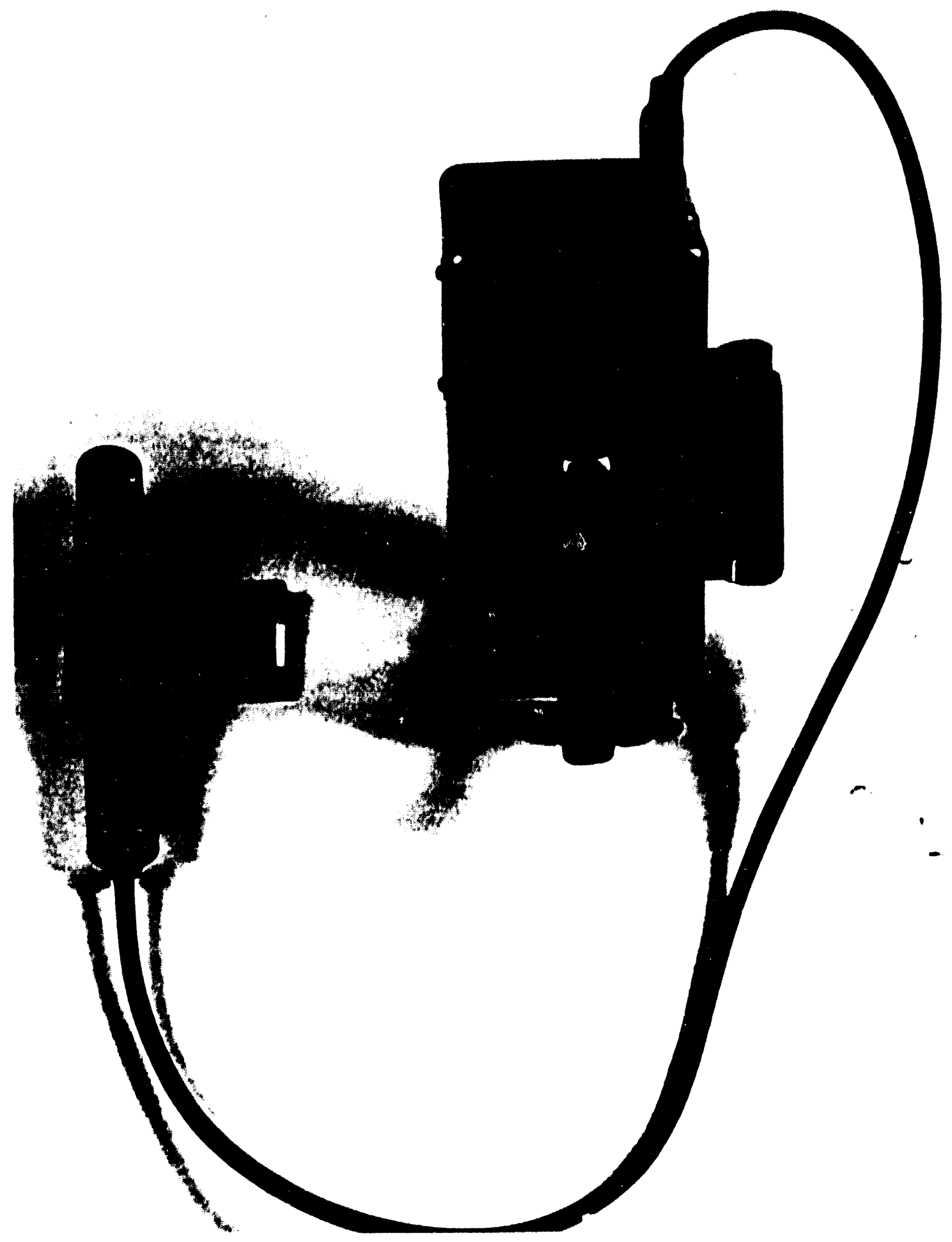

Fig. 2. Placement of open side-window probe of a Geiger-Mueller Survey Meter for direct reading of the indium foil in a security badge. 


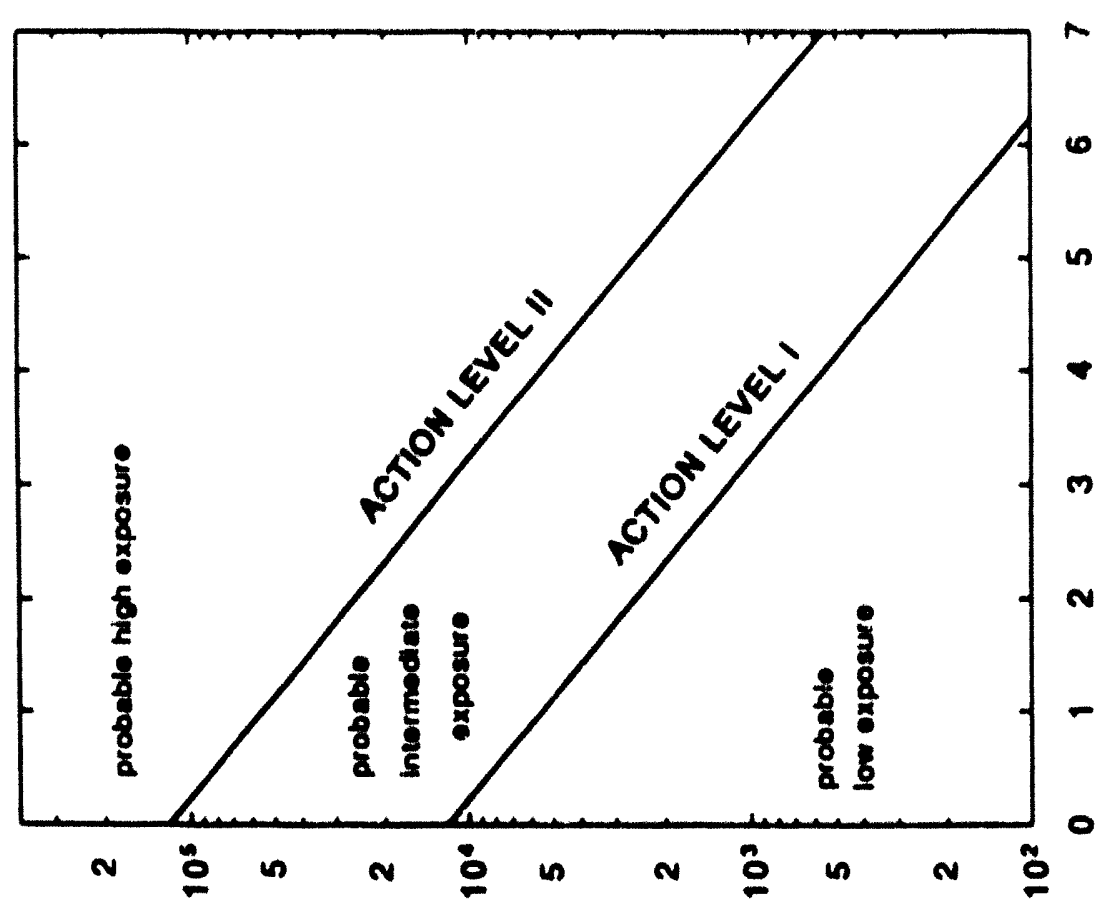

(wdo) ONIOVヨY WSWO BXYYNYd

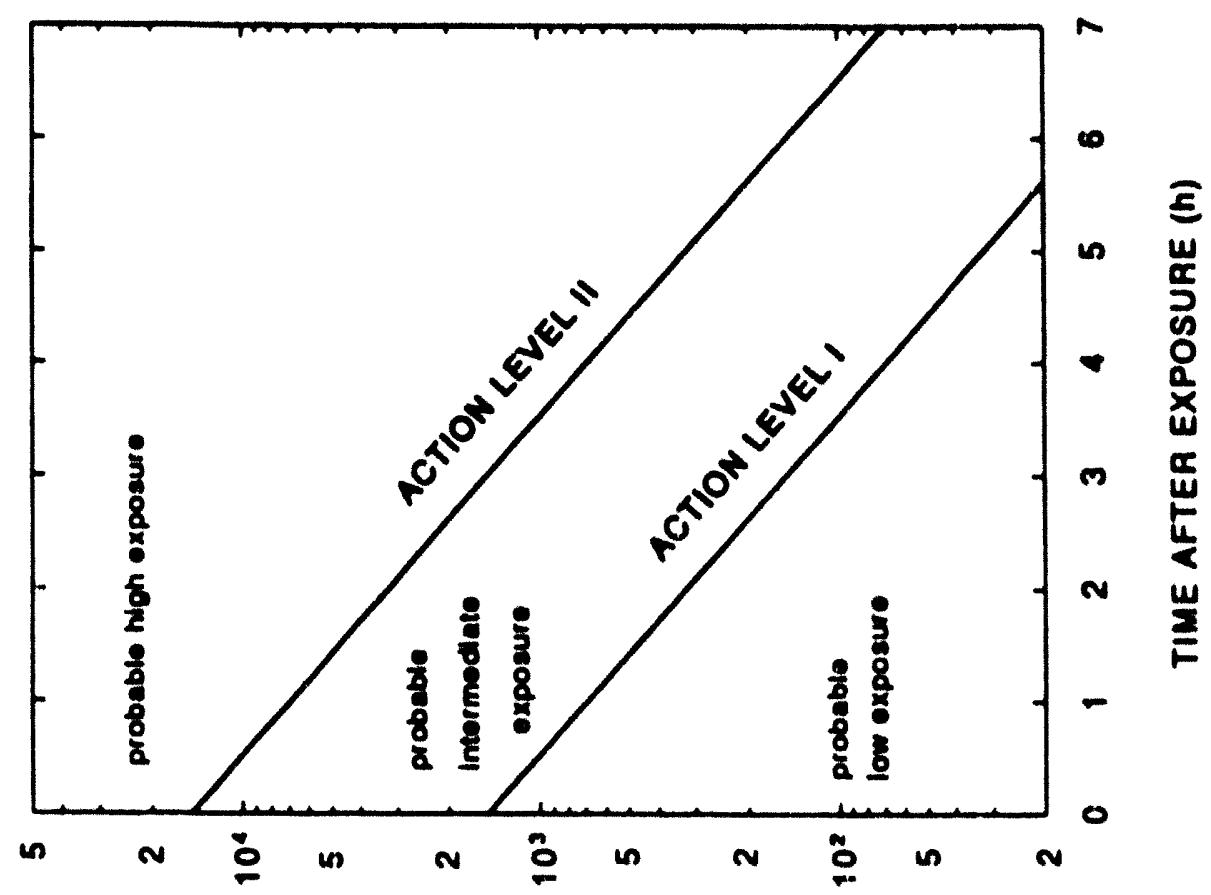

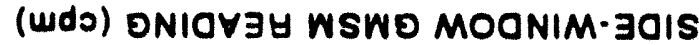

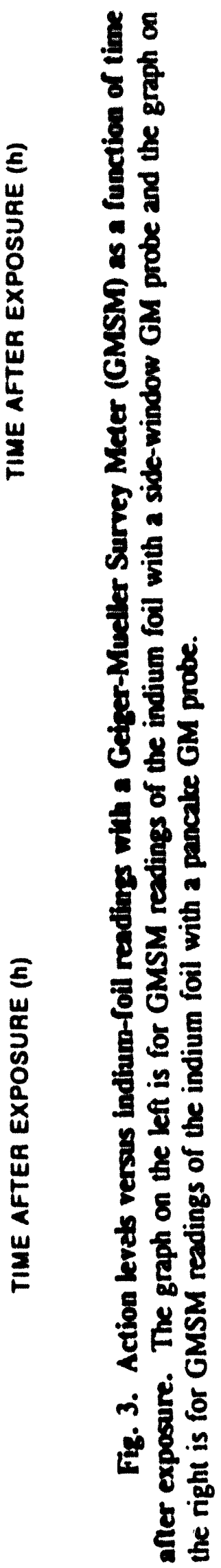


half-life of $15 \mathrm{~h}$, and the Action Levels $\mathrm{I}$ and II correspond to count rates (minus background) of approximately 25 and $250 \mathrm{cpm}$, respectively.?

The personnel dosimeters of all individuals should be assigned a priority for analysis as follows: the highest priority should be above Action Level II (a probable high exposure), the next priority should be between Action Levels I and II (a probable intermediate exposure), and the lowest priority should be below Action Level I (a probable low exposure). All individuals classified as having a probable high exposure (by either screening method) should be escorted as soon as possible to the Health Division (via a decontamination facility, if necessary) for co!lection of blood and hair samples and for medical surveillance. These persons should also be questioned in detail about their locations and activities at the time of the accident. Other persons classified as having an probable intermediate exposure (by either screening method) should also be questioned in more detail and escorted to the Health Division (via a decontamination facility, if necessary) for collection of hair and blood samples. Action Levels I and $\mathrm{II}$ are intended only for rapid identification of personnel exposures in descending order from most-to-least severe, and the estimated absorbed doses associated with these action levels are considered too unreliable for use even as preliminary data. ${ }^{6,8}$

\subsection{BLOOD SODIUM ACTIVATION}

Detailed procedures have been devel. 20 for the collection and analysis of blood samples to determine the specific activity of blood sodium (i.e., Bq of ${ }^{24} \mathrm{Na}$ per gram of ${ }^{23} \mathrm{Na}$ ). A blood sample of about $20 \mathrm{~mL}$ will be collected in two 10-mL vacutainers, allowed to clot for 25-30 min, and centrifuged. The serum will then be drawn off using a plastic transfer pipette and sealed in a $20-\mathrm{mL}$ scintillation vial using the screw on top. The scintillation vial will be weighted to determined the mass of the serum sample (i.e., the mass of both the serum and vial minus the mass of the empty vial), and the volume of the sample will be calculated using a serum density of $1.03 \mathrm{~g} / \mathrm{mL}$ (ref. 9). The blood serum is used in the analysis because there is less variation in the ${ }^{23} \mathrm{Na}$ concentrations than in whole blood. Sodium-23 is contained at concentrations of approximately $1.92 \mathrm{mg} / \mathrm{mL}( \pm 10 \%)$ in whole blood ${ }^{10-11}$ and $3.25 \mathrm{mg} / \mathrm{mL}$ $( \pm 4 \%)$ in blood serum, ${ }^{4.12}$ where the uncertainty is based on normal biological variability among 
healthy adult males and females. The expected yield of blood serum per 20-mL sample of whole blood is 10-15 mL (ref. 12, Tables 20-25).

The specific activity of a serum sample can be measured on two different counting systems using high-resolution germanium detectors: one with an active detector volume of $100 \mathrm{~cm}^{3}$ (and efficiency of 13\%) from Tennelec/Nucleus, Inc.; or another with an active detector volume of $168 \mathrm{~cm}^{3}$ (and efficiency of $44 \%$ ) from Princeton Gamma-Tech, Inc. These two counting systems are maintained under stringent quality assurance standards because they are used routinely in the analysis of bioassay, air-filter, and smear samples. Calibrations for all sample geometries have been established using an Amersham Corporation QCY.48 mixedgamma-radiation source. The calibration data for a $15-\mathrm{mL}$ sample and the $168-\mathrm{cm}^{3}$ germanium detector are shown in Fig. 4. To avoid contamination of the detectors, samples were placed inside a Marinelli beaker and centered over the top surface of the cylindrical detectors. A serum sample can be diluted if necessary with distilled water to the calibration volume of $15 \mathrm{~mL}$. The specific antivity of a serum sample is calculated as a weighted mean using the measurements and the standard deviations of the measurements for both the 1369- and 2754-keV gamma rays from ${ }^{24} \mathrm{Na}$ (ref. 13). Specific activities corresponding to $0.01 \mathrm{~Gy}$ (1 rad) can be counted in a normal blood serum sample with a statistical accuracy of approximately $10 \%$ at counting times of $10 \mathrm{~min}$ for a highly thermalized neutron spectrum and $30 \mathrm{~min}$ for a unmoderated fission neutron spectrum. ${ }^{14}$ The serum sample should be maintained so that the actual ${ }^{23} \mathrm{Na}$ concentration can be determined later using one of several different techniques., ${ }^{2,12}$

The specific activity, $A$, of body sodium can be related to the neutron fluence, $\phi$, incident on the body by use of a quantity, $\xi$, called the neutron capture probability-the fraction of the neutrons incident on the body that are captured within the body. Figure 5 shows the neutron capture probability for neutrons incident on the front of a realistic adult-male analogue or socalled BOMAB phantom. ${ }^{15}$ Body sodium is readily activated by incident neutrons of all energies, but the neutron energy spectrum must be specified to determine the absorbed dose. The absorbed dose, $D$, from neutrons at the surface of the body facing the source can be related to the specific activity, $A$, of body sodium by the equation: 


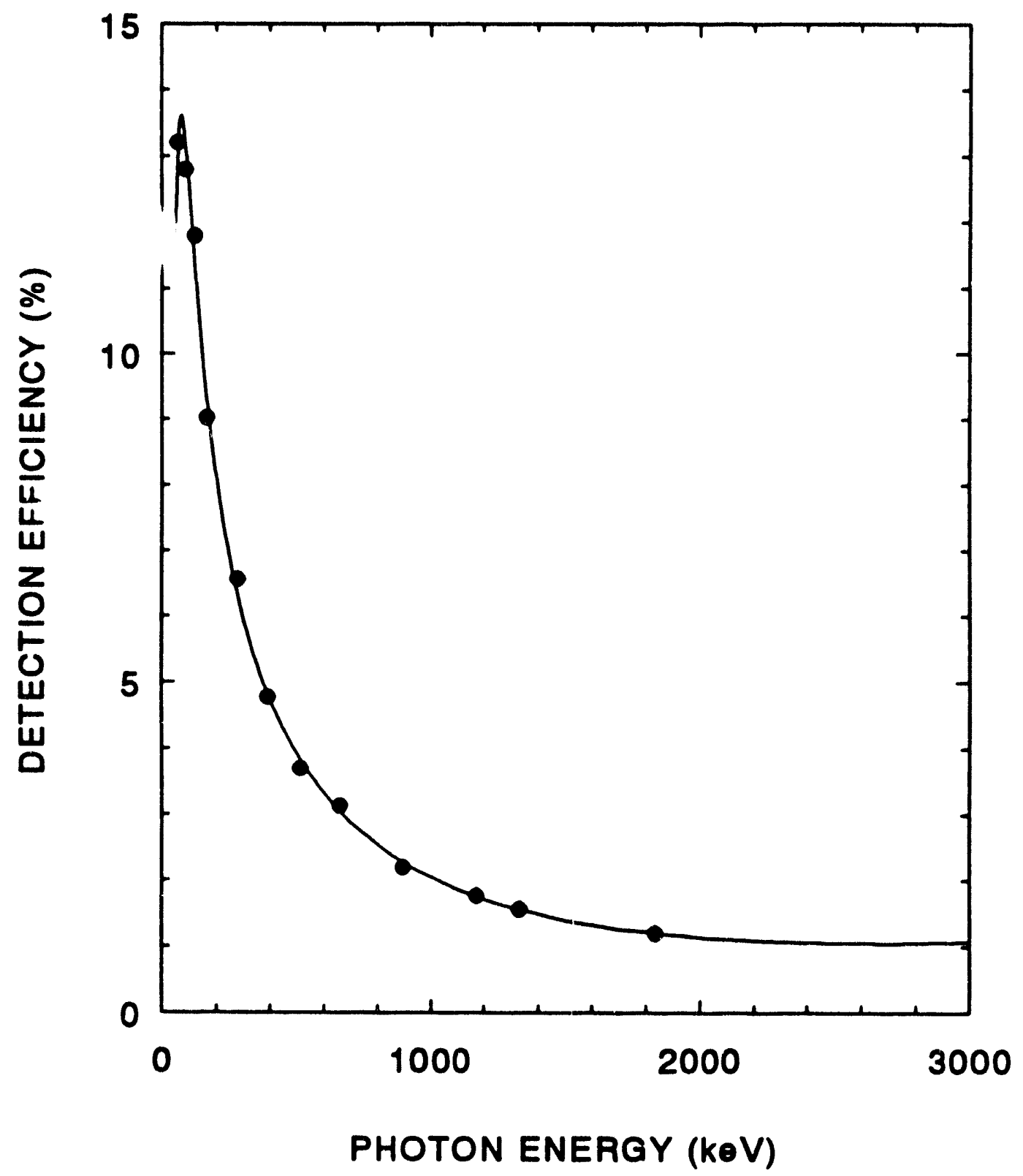

Fig. 4. Calibration data for a 15-mL sample centered on the top surface of the cylindrical 168- $\mathrm{cm}^{3}$ germanium detector. The ircles show measured points for twelve photon energies between 59.54 and $183 \quad \checkmark$, and the solid line shows the results of an empirical fit to a fifth-degree poi mial. The results of the empirical fit predict detection efficiencies of 1.52 and $1.05 \%$ for the 1369- and 2754-keV gamma rays, respectively, from ${ }^{24} \mathrm{Na}$. 


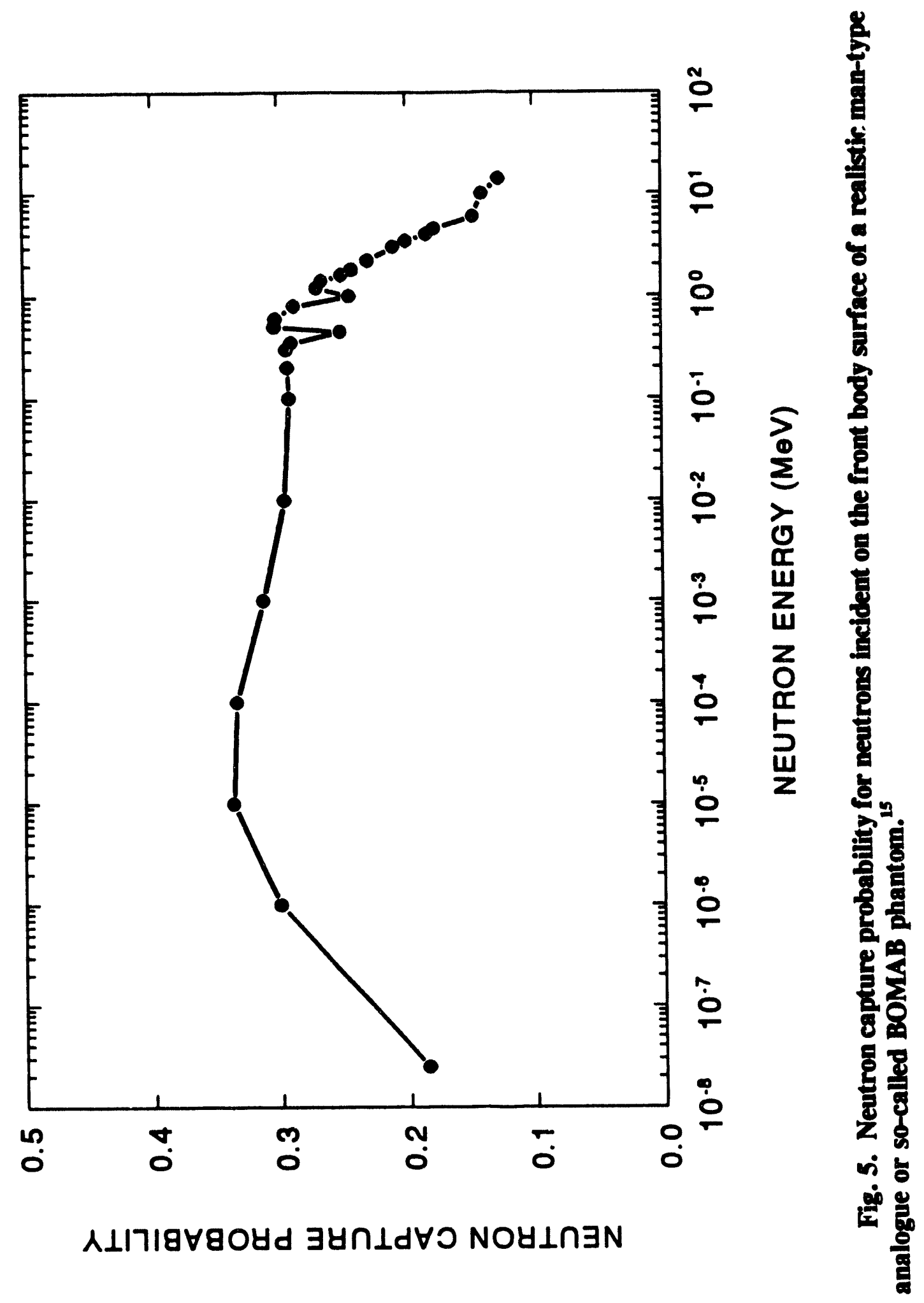




$$
\frac{D}{A}=\frac{\int D(E) \phi(E) d E}{\left(\frac{\lambda \Sigma_{N_{e}}}{C_{N_{Q}} \Sigma_{\imath}}\right)\left(\frac{S}{V}\right) \int E(E) \phi(E) d E},
$$

where $E$ is the neutron energy, $S$ is the cross-sectional area of the body for neutrons normally incident on the front (or back) of the body, $V$ is the total volume of the body, $\Sigma_{i}$ is the total macroscopic cross section for absorption of neutrons in the body, $\Sigma_{N a}$ is the macroscopic cross section for thermal neutron capture in ${ }^{23} \mathrm{Na}$ of the body, $\mathrm{C}_{\mathrm{Na}}$ is the concentration of ${ }^{23} \mathrm{Na}$ in the body, and $\lambda$ is the decay constant for ${ }^{21} \mathrm{Na}$ (ref. 14). Because the equation is for specific activity of body sodium, the results are applicable to both the activation of sodium in the body and in the blood that is circulating within the body. The specific activity can be converted to activity per unit volume by using the previously cited values of $1.92 \mathrm{mg}$ of ${ }^{23} \mathrm{Na}$ per $\mathrm{mL}$ of whole blood and $3.25 \mathrm{mg}$ of ${ }^{23} \mathrm{Na}$ per $\mathrm{mL}$ of blood serum.

Table 1 gives body sodium-to-absorbed dose conversion factors for a collection of 98 neutron spectra. ${ }^{14}$ The absorbed doses are those for the neutron recoil-ion component at the surface of the body facing the source as shown in Fig. 6 (i.e., the absorbed dose in volume element 57 of the cylindrical phantom from the calculations of Auxier et al. ${ }^{19}$ ). The use of Table 1 in the calculation of absorbed dose from neutrons is simple if the following information is available: (1) the form of the fission material such as a metal or solution; (2) the thicknesses and types of shielding materials such as iron, lead, or concrete; and (3) the thicknesses and types of any moderating or reflecting materials such as water, graphite, or beryllium. If it is determined later that the body was irradiated primarily from the side, then the absorbed dose calculated by application of the data in Table 1 must be doubled because of the differences in $S$ (the cross-sectional area of the body) for irradiation from the side and from the front (or back). The capture gamma-ray component of neutron absorbed dose, as shown in Fig. 6, is not included in the calculation because it would be measured by the gamma-ray detectors of a personnel dosimeter. 
Table 1. Factors for converting specinc activity of blood serum (Bq of ${ }^{2} \mathrm{Na}$ per gram of ${ }^{2} \mathrm{Na}$ ) to absorbed dose (Gy) at surface of body facing toward the source ${ }^{14}$

Spectrum description

Spectra of fission neutrons from selected critical assemblies

Uncollided fission spectrum

HPRR spectrum at $3 \mathrm{~m}$ with no shielding

HPiRR spectrum at $3 \mathrm{~m}$ with $12 \mathrm{~cm}$ of Lucite shielding

HPRR spectrum at $3 \mathrm{~m}$ with $13 \mathrm{~cm}$ of steel shielding

HPRR spectrum at $3 \mathrm{~m}$ with $20 \mathrm{~cm}$ of concrete shielding
Gy $\mathbf{~ B q}^{-1}$

$2.262 \mathrm{E}-4$

$1.054 \mathrm{E}-4$

$1.052 E-4$

7.601E-5

5.545E-5

Spectra of fission neutrons from critical solutions

Fissile $\mathrm{H}_{2} \mathrm{O}$ solution, spherical geometry, $2-\mathrm{cm}$ radius

Fissile $\mathrm{H}_{2} \mathrm{O}$ solution, spherical geometry, 5 -cm radius

$1.892 \mathrm{E}-4$

$1.570 \mathrm{E}-4$

$1.464 \mathrm{E}-4$

Fissile $\mathrm{H}_{2} \mathrm{O}$ solution, spherical geometry, $10-\mathrm{cm}$ radius

$1.427 \mathrm{E}-4$

$1.415 E-4$

Fissile $\mathrm{H}_{2} \mathrm{O}$ solution, spherical geomeary, $30-\mathrm{cm}$ radius

$1.978 E-4$

$7.994 \mathrm{E}-5$

Fissile $D_{2} 0$ solution, spherical geometry, $2-\mathrm{cm}$ radius

Fissile $D_{2} O$ solution, spherical geometry, $30-\mathrm{cm}$ radius

$7.610 \mathrm{E}-5$

Spectra of fission neutrons through various shielding materials

Fission neutrons through $5 \mathrm{~cm}$ of $\mathrm{H}_{2} \mathrm{O}$

$1.397 \mathrm{E}-4$

$1.682 \mathrm{E}-4$

$1.920 \mathrm{E}-4$

Fission neutrons through $30 \mathrm{~cm}$ of $\mathrm{H}_{2} \mathrm{O}$

$2.175 \mathrm{E}-4$

Fission neutrons through $50 \mathrm{~cm}$ of $\mathrm{H}_{2} \mathrm{O}$

Fission neutrons through $2 \mathrm{~cm}$ of $\mathrm{H}_{2} \mathrm{O}$ at surface

$1.599 \mathrm{E}-4$

$1.868 \mathrm{E}-4$

Fission neutrons through $2 \mathrm{~cm}$ of $\mathrm{D}_{2} \mathrm{O}$

Fission neutrons through $5 \mathrm{~cm}$ of $\mathrm{D}_{2} \mathrm{O}$

8.388E-5

$5.104 \mathrm{E}-5$

$4.498 \mathrm{E}-5$

$1.754 \mathrm{E}-4$

Fission neutrons through $30 \mathrm{~cm}$ of $\mathrm{D}_{2} \mathrm{O}$

Fission neutrons through $2 \mathrm{~cm}$ of $\mathrm{D}_{2} \mathrm{O}$ at surface

2.251E-4

Fission neutrons through $5 \mathrm{~cm}$ of graphite

Fission neutrons through $10 \mathrm{~cm}$ of graphite

Fission neutrons through $20 \mathrm{~cm}$ of graphite

Fission neutrons through $40 \mathrm{~cm}$ of grannite

Fission neutrons through $60 \mathrm{~cm}$ of graphite

Fission neutrons through $10 \mathrm{~cm}$ of polyethylene

Fission neutrons through $20 \mathrm{~cm}$ of polyethylene

Fission neutrons through $40 \mathrm{~cm}$ of polyethylene

Fission neutrons through $60 \mathrm{~cm}$ of polyethylene

$1.982 \mathrm{E}-4$

$1.328 \mathrm{E}-4$

$6.540 \mathrm{E}-5$

$4.760 \mathrm{E}-5$

$1.221 \mathrm{E}-4$

$1.270 \mathrm{E}-4$

$1.474 \mathrm{E}-4$

$1.620 \mathrm{E}-4$

$1.474 \mathrm{E}-4$

$1.423 \mathrm{E}-4$

$1.556 \mathrm{E}-4$

$1.800 \mathrm{E}-4$

$1.947 \mathrm{E}-4$

$2.136 \mathrm{E}-4$

Fission neutrons through $60 \mathrm{~cm}$ of $1 \%$ borated polyethylene

Fission neutrons through $2.5 \mathrm{~cm}$ of beryllium 
Table 1 (continued)

\begin{tabular}{|c|c|}
\hline Spectrum description & Gy $\mathrm{Bg}^{-1}$ \\
\hline $\begin{array}{l}\text { Fission neutrons through } 5 \mathrm{~cm} \text { of beryllium } \\
\text { Fission neutrons through } 10 \mathrm{~cm} \text { of beryllium } \\
\text { Fission neutrons through } 20 \mathrm{~cm} \text { of beryllium } \\
\text { Fission neutrons through } 30 \mathrm{~cm} \text { of beryllium } \\
\text { Fission neutrons through } 2.5 \mathrm{~cm} \text { of aluminum } \\
\text { Fiasion neutrons through } 10 \mathrm{~cm} \text { of aluminum } \\
\text { Fission neutrons through } 20 \mathrm{~cm} \text { of aluminum } \\
\text { Fission neutrons through } 40 \mathrm{~cm} \text { of aluminum } \\
\text { Fission neutrons through } 10 \mathrm{~cm} \text { of concrete } \\
\text { Fission neutrons through } 20 \mathrm{~cm} \text { of concrete } \\
\text { Fission neutrons through } 30 \mathrm{~cm} \text { of concrete } \\
\text { Fission neutrons through } 40 \mathrm{~cm} \text { of concrete } \\
\text { Fission neutrons through } 60 \mathrm{~cm} \text { of concrete } \\
\text { Fission neutrons through } 5 \mathrm{~cm} \text { of concrete with } 10 \% \text { iron } \\
\text { Fission neutrons through } 10 \mathrm{~cm} \text { of concrete with } 10 \% \text { iron } \\
\text { Fission neutrons through } 20 \mathrm{~cm} \text { of concrete with } 10 \% \text { iron } \\
\text { Fission neutrons through } 60 \mathrm{~cm} \text { of concrete with } 10 \% \text { iron } \\
\text { Fission neutrons through } 100 \mathrm{~cm} \text { of concrete with } 10 \% \text { iron } \\
\text { Fission neutrons through } 5 \mathrm{~cm} \text { of concrete with } 50 \% \text { iron } \\
\text { Fission neutrons through } 10 \mathrm{~cm} \text { of concrete with } 50 \% \text { iron } \\
\text { Fission neutron through } 20 \mathrm{~cm} \text { of concrete with } 50 \% \text { iron } \\
\text { Fission neutrons through } 60 \mathrm{~cm} \text { of concrete with } 50 \% \text { iron } \\
\text { Fission neutrons through } 100 \mathrm{~cm} \text { of concrete with } 50 \% \text { iron } \\
\text { Fission neutrons through } 5 \mathrm{~cm} \text { of iron } \\
\text { Fission neutrons through } 10 \mathrm{~cm} \text { of iron } \\
\text { Fission neutrons through } 20 \mathrm{~cm} \text { of iron } \\
\text { Fission neutrons through } 30 \mathrm{~cm} \text { of iron } \\
\text { Fission neutrons through } 50 \mathrm{~cm} \text { of iron } \\
\text { Fission neutrons through } 100 \mathrm{~cm} \text { of iron } \\
\text { Fission neutrons through } 5 \mathrm{~cm} \text { of copper } \\
\text { Fission neutrons through } 10 \mathrm{~cm} \text { of lead } \\
\text { Fission neutrons through } 20 \mathrm{~cm} \text { of lead } \\
\text { Fission neutrons through } 30 \mathrm{~cm} \text { of lead } \\
\text { Fission neutrons through } 50 \mathrm{~cm} \text { of lead } \\
\text { Fission neutrons through } 5 \mathrm{~cm} \text { of depleted uranium } \\
\text { Fission neutrons through } 10 \mathrm{~cm} \text { of depleted uranium } \\
\text { Fission neutrons through } 20 \mathrm{~cm} \text { of depleted uranium } \\
\text { Fission neutrons through } 30 \mathrm{~cm} \text { of depleted uranium }\end{array}$ & $\begin{array}{l}1.840 \mathrm{E}-4 \\
1.213 \mathrm{E}-4 \\
6.754 \mathrm{E}-5 \\
5.148 \mathrm{E}-5 \\
2.302 \mathrm{E}-4 \\
2.003 \mathrm{E}-4 \\
1.450 \mathrm{E}-4 \\
6.663 \mathrm{E}-5 \\
1.441 \mathrm{E}-4 \\
1.024 \mathrm{E}-4 \\
8.705 \mathrm{E}-5 \\
8.719 \mathrm{E}-5 \\
9.779 \mathrm{E}-5 \\
2.021 \mathrm{E}-4 \\
1.586 \mathrm{E}-4 \\
1.093 \mathrm{E}-4 \\
7.749 \mathrm{E}-5 \\
7.312 \mathrm{E}-5 \\
1.999 \mathrm{E}-4 \\
1.534 \mathrm{E}-4 \\
9.927 \mathrm{E}-5 \\
6.375 \mathrm{E}-5 \\
5.882 \mathrm{E}-5 \\
1.828 \mathrm{E}-4 \\
1.473 \mathrm{E}-4 \\
9.688 \mathrm{E}-5 \\
7.200 \mathrm{E}-5 \\
5.078 \mathrm{E}-5 \\
2.947 \mathrm{E}-5 \\
1.635 \mathrm{E}-4 \\
1.825 \mathrm{E}-4 \\
1.425 \mathrm{E}-4 \\
1.120 \mathrm{E}-4 \\
7.276 \mathrm{E}-5 \\
1.548 \mathrm{E}-4 \\
1.106 \mathrm{E}-4 \\
6.841 \mathrm{E}-5 \\
5.133 \mathrm{E}-5\end{array}$ \\
\hline \multicolumn{2}{|l|}{ Spectra of moderated $\mathrm{H}_{2} \mathrm{O}$ fission neutrons through shielding materials } \\
\hline $\begin{array}{l}\text { Moderated } \mathrm{H}_{2} \mathrm{O} \text { fission neutrons through } 2.5 \mathrm{~cm} \text { of beryllium } \\
\text { Moderated } \mathrm{H}_{2} \mathrm{O} \text { fission neutrons through } 5 \mathrm{~cm} \text { of beryllium } \\
\text { Moderated } \mathrm{H}_{2} \mathrm{O} \text { fission neutrons through } 10 \mathrm{~cm} \text { of beryllium } \\
\text { Moderated } \mathrm{H}_{2} \mathrm{O} \text { fission neutrons through } 20 \mathrm{~cm} \text { of beryllium } \\
\text { Moderated } \mathrm{H}_{2} \mathrm{O} \text { fission neutrons through } 10 \mathrm{~cm} \text { of aluminum } \\
\text { Moderated } \mathrm{H}_{2} \mathrm{O} \text { fission neutrons through } 20 \mathrm{~cm} \text { of aluminum } \\
\text { Moderated } \mathrm{H}_{2} \mathrm{O} \text { fission neutrons through } 10 \mathrm{~cm} \text { of concrate } \\
\text { Moderated } \mathrm{H}_{2} \mathrm{O} \text { fission neutrons through } 20 \mathrm{~cm} \text { of concrete } \\
\text { Moderated } \mathrm{H}_{2} \mathrm{O} \text { fission neutrons through } 30 \mathrm{~cm} \text { of concrete }\end{array}$ & $\begin{array}{l}1.103 \mathrm{E}-4 \\
1.024 \mathrm{E}-4 \\
8.191 \mathrm{E}-5 \\
5.735 \mathrm{E}-5 \\
8.369 \mathrm{E}-5 \\
6.025 \mathrm{E}-5 \\
8.864 \mathrm{E}-5 \\
7.877 \mathrm{E}-5 \\
8.177 \mathrm{E}-5\end{array}$ \\
\hline
\end{tabular}


Table 1 (conlinued)

Spectrum description

Moderated $\mathrm{H}_{2} \mathrm{O}$ fission neutrons through $20 \mathrm{~cm}$ of iron Moderated $\mathrm{H}_{2} \mathrm{O}$ fission neutrons through $50 \mathrm{~cm}$ of iron Moderated $\mathrm{H}_{2} \mathrm{O}$ fission neutrons through $5 \mathrm{~cm}$ of copper Moderated $\mathrm{H}_{2} \mathrm{O}$ fission neutrons through $10 \mathrm{~cm}$ of copper Moderated $\mathrm{H}_{2} \mathrm{O}$ fission neutrons through $20 \mathrm{~cm}$ of copper Moderated $\mathrm{H}_{2} \mathrm{O}$ fission neutrons through $30 \mathrm{~cm}$ of copper Moderated $\mathrm{H}_{2} \mathrm{O}$ fission neutrons through $50 \mathrm{~cm}$ of copper Moderated $\mathrm{H}_{2} \mathrm{O}$ fission neutrons through $5 \mathrm{~cm}$ of lead Moderated $\mathrm{H}_{2} \mathrm{O}$ fission neutrons through $10 \mathrm{~cm}$ of lead Moderated $\mathrm{H}_{2} \mathrm{O}$ fission neutrons through $30 \mathrm{~cm}$ of lead Moderated $\mathrm{H}_{2} \mathrm{O}$ fission neutrons through $50 \mathrm{~cm}$ of lead
Gy \& Bq.1

6.822E-5

4.357E-5

8.755E-5

7.385E-5

5.367E-5

4.198E-5

3.185E-5

9.745E-5

9.020E-5

6.497E-5

4.971E-5

Spectra of fission neutrons from a small ${ }^{202} \mathrm{Cf}$ source"

Fission noutrons from ${ }^{20} \mathrm{Cf}$ with no shielding

$2.351 E-4$

$\mathrm{D}, \mathrm{O}$-moderated fission neutrons from ${ }^{20} \mathrm{Cf}$ 6.061E-5

The neutroa eacrgy spectra are from tables in the appendices of the report by Ing and Makra," unleas noted otherwise.

See ref. 17.

See ref. 18. 


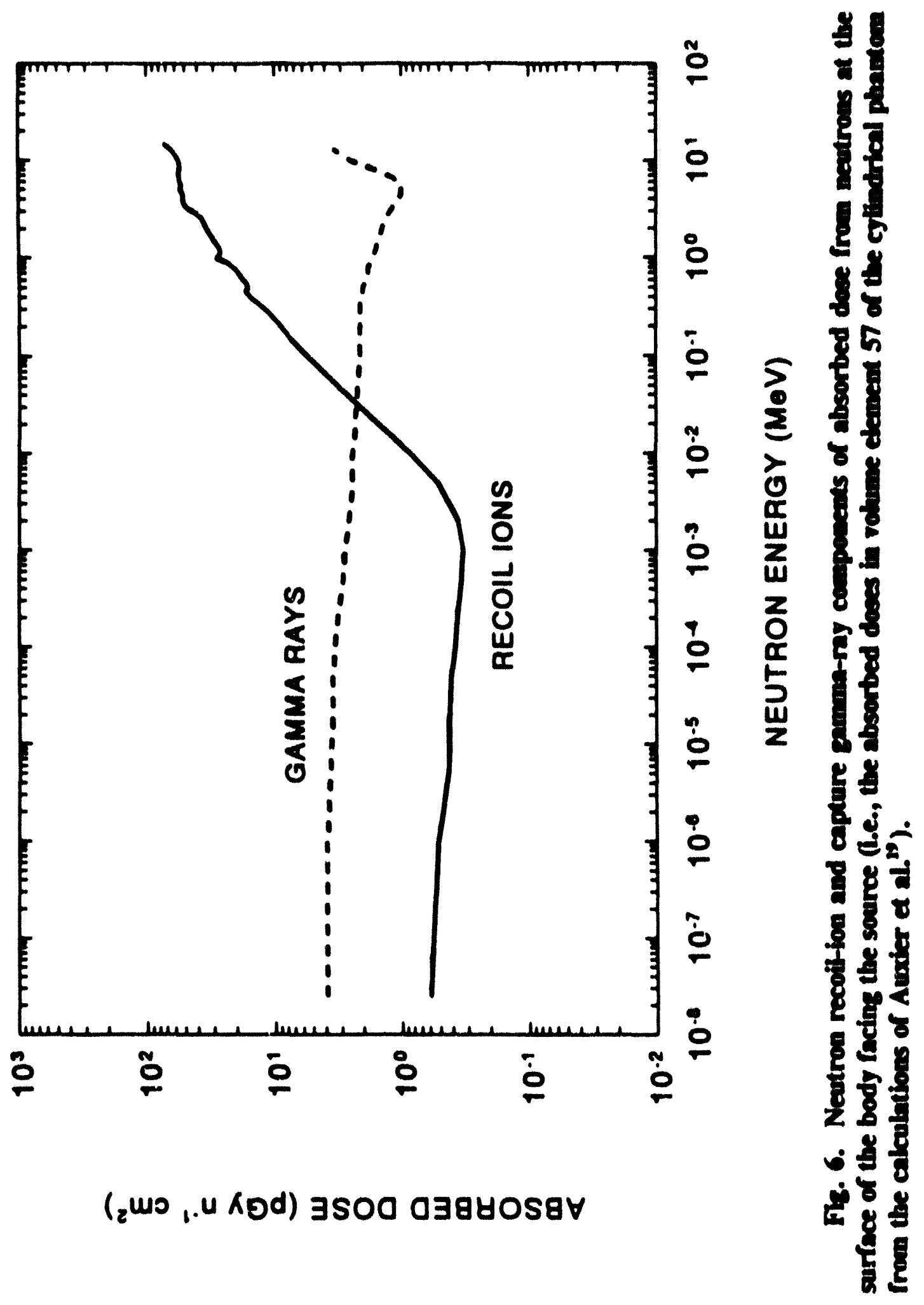




\subsection{HATR SULFUR ACTIVATION}

Detailed procedures have also been developed for the collection and analysis of hair samples to determine the specific activity of "PP (i.e., Bq of "2P per gram of hair). The hair contains almost no phosphorus except that contributed by epidermal cell fragnents and external contumination, and the "3p activity in hair can be attributed almost entirely to the ${ }^{32} S(n, p){ }^{32} p$ reaction. ${ }^{20}$ Sulfur is maturally present in hair at a concentration of $45 \mathrm{mg} / \mathrm{g}$ of hair with little variation from individual to individual or with anatomical distribution. 21.n The "P activity in hair can be used, therefore, to determine: (1) the fast neutron fluence above the effective threahold energy of approximately $3 \mathrm{MeV}$ for the ${ }^{n} \mathrm{~S}(n, p)^{n} \mathrm{P}$ reaction; ${ }^{23}$ and (2) the person's orientation by collecting hair samples with masses of several tenths of a gram to several grams from as many anatomical sites as possible (i.e., the head, chest, abdomen, pubis, and legs). At a minimum, hair samples should be collected from the top and back of the head and the pubic region of the body. ${ }^{2}$

Phosphorus-32 decays with a half-life of $14.3 \mathrm{~d}$ and emits only beta particles with a maximum energy of $1.7 \mathrm{MeV}$ (ref. 13). Because "P is a pure beta-particle emitter, the specific activity of the hair samples will be determined using Packard Instrument Company's Tri-Cart Liquid Scintillation Counter, Model 2000CA/LL. This counting system is maintained under stringent quality assurance standards because it is used routinely in the analysis of bioassay, airfilter, and smear samples. A hair sample can be prepared for analysis using either of two different methods: (1) chemical discolution of the hair followed by dilution in a liquid scintillator; or (2) ashing of the hair followed by suspension in a liquid scintillator. Because of the effects of both color and chemical quenching in liquid scintillators, the detection efficiency must be determined by "P spiking of samples prepared in the same manner using unirradiated hair. The detection efficiency for beta particles from ${ }^{2} \mathrm{P}$ in hair samples prepared by either of the two methods was greater than $95 \%$ (ref. 14).

Hair samples should be washed and dried prior to counting. ${ }^{2.21}$ In the chemical dissolution method recommended by Feng et al., "it was found that a hair sample of up to $0.5 \mathrm{~g}$ could be prepared for counting as follows: (1) weigh the dried hair sample and place it in small flask; (2) add Fisher Scientific's ScintiGest Tissue Solubilizer (14 mL/g of hair); (3) add 30\% hydrogen peroxide ( $7 \mathrm{~mL} / \mathrm{g}$ of hair); (3) add Fisher Scientific's Dithiothreitol $(0.12 \mathrm{~g} / \mathrm{g}$ of hair); 
(4) heat the solution for $3-4 \mathrm{~h}$ at a temperature of $50-60^{\circ} \mathrm{C}$; and (5) add liquid scintillator. One milliliter of sample can be mixed with $15 \mathrm{~mL}$ of Opti-Fluor liquic scintillator (a product of Packard Instrument Company), or up $105 \mathrm{~mL}$ of sample can be mixed with Ultima-Gold liquid scintillator (also from Packard Instrument), for counting purposes. In the ashing preparation method of Feng et al., ${ }^{14}$ the hair sample was weighted, placed in a small crucible, and ashed in a Muffe fumace at a lemperature of approximately $800^{\circ} \mathrm{C}$. After ashing, 1-g hair was reduced to a fine power with a weight of about $0.008 \mathrm{~g}$ which was suspended in a liquid scintillator using Fisher Sciendific's Triton-100. If a hair ample of more than $0.3 \mathrm{~g}$ was used, the ashing of hair was recommended 10 obtain less quenching of the liquid scintillator. ${ }^{14}$ The precision of the ashing preparation method depends on the degree of suspension and care of operation because the loss of ashed hair from small samples can have a remarkable affect on the specific activity (Bq of "P per gram of hair). A portion of each hair sample should be maintained for later determination of the actual concentration of sulfur in the hair from an exposed individual."

Because sulfur is activated by neutrons with energies greater than $3 \mathrm{MeV}$, the specific activity is greatly reduced if the hair was shielded by the body (e.8. , the hair on the back of the head of an individual facing the source). Thus, the hair ample giving the highest specific activity, together with other information obtained from the individual, can be used to make a determination of the individual's orientation during their exposure. The specific activity, A, of np in hair on the side of the body facing the source can be calculated by the equation:

$$
A=\frac{\lambda_{1} C_{2}}{M} \int \sigma_{0}(E)(E) d E
$$

where $\lambda$ is the decay constant for ${ }^{32} \mathrm{P}, C_{d}$ is the concentration of sulfur in hair, $M$ is the atomic weight of sulfur, $A_{0}$ is Avogadro's number, $E$ is the neutron energy, $\phi$ is the neutron fluence as a function of neutron energy, and $\sigma$ is the cross soction for the ${ }^{32} S(n, p){ }^{32} \mathrm{p}$ reaction as illustrated in Fig. 7 (ref. 25). Table 2 gives ratios for the sperific activities of ${ }^{33} \mathrm{P}$ in hair to ${ }^{2} \mathrm{Na}$ in blood serum (i.e., $A_{\mathrm{Had}} / A_{N_{e}}$ ) that were calculated using Eq. (2) and the denominator of Eq. (1) (ref. 14). 


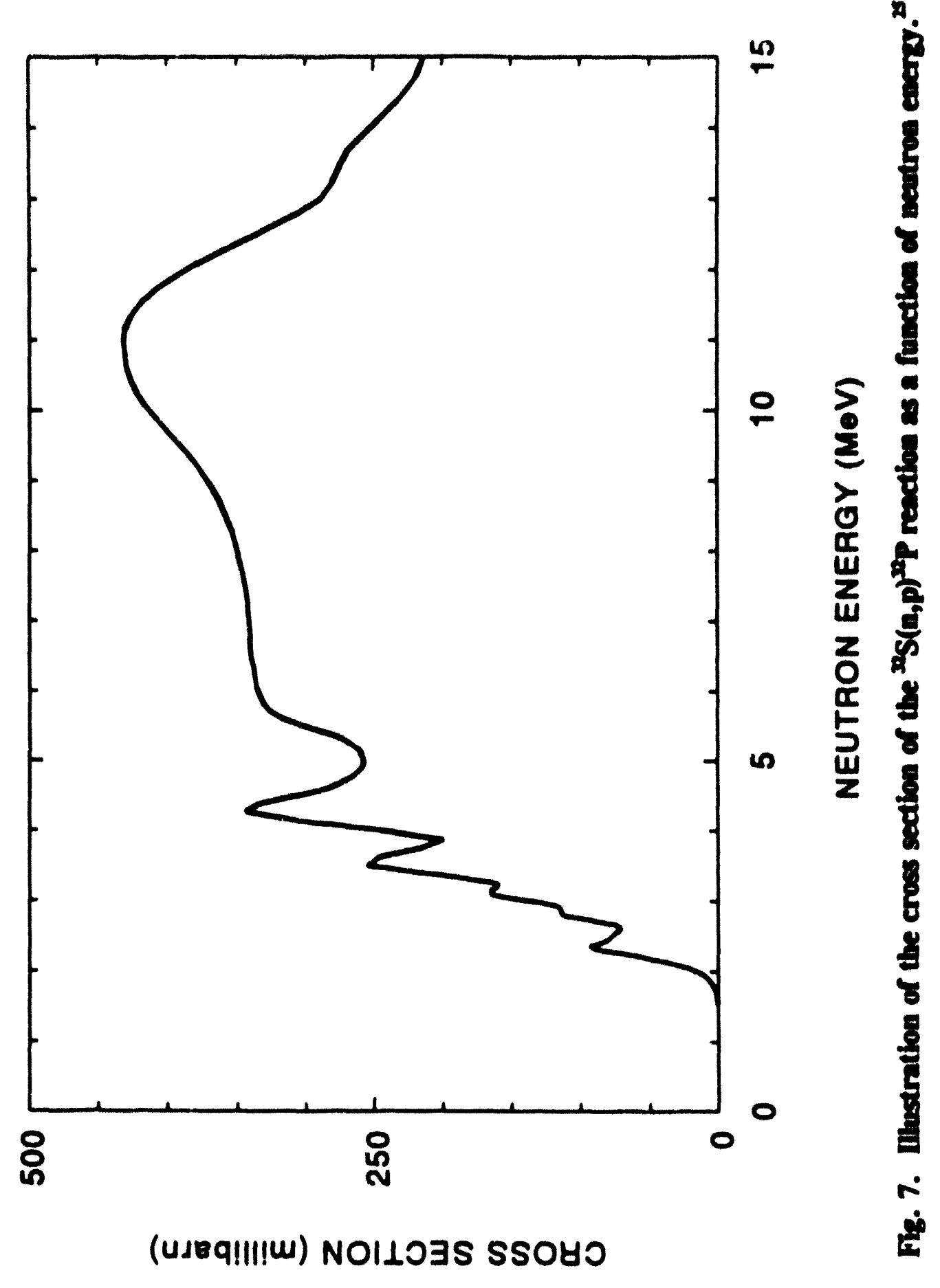


Table 2. Ratios of the specinc activity of sulfur in hair

(Bq of "P per gram of huir) to the specilik activity of blood serum (Bq of 2Na per gram of ${ }^{2} \mathrm{Na}$ )"

$\begin{array}{ll}\text { Spectrum description } & \text { Ratio }\end{array}$

Spectra of fission neutrons from selected critical seemblice

Uncollided fisslon spectrum

HPRR spectrum a $3 \mathrm{~m}$ with no shiolding

HPRR spectrum it $3 \mathrm{~m}$ with $12 \mathrm{~cm}$ of Lucite shielding

HPRR epectrum a $3 \mathrm{~m}$ with $13 \mathrm{~cm}$ of sted shielding

HPRR epectrum a $3 \mathrm{~m}$ with $20 \mathrm{~cm}$ of coscrete shididing

$2.29 \mathrm{E}-4$

7.00E-5

7.87E-5

2.18E-5

2.07E-5

Spectra of fission noutrons from critical solutions

Fiaslle $\mathrm{H}_{2} \mathrm{O}$ solution, spherical geometry, $2-\mathrm{cm}$ radius

Fisalle Hy solution, spherical geomatry, $5-\mathrm{cm}$ radius

$1.86 \mathrm{E}-4$

$1.52 \mathrm{E}-4$

Fissile $\mathrm{H}_{2} \mathrm{O}$ solution, spherical geomery, $10-\mathrm{cm}$ radius

$1.41 \mathrm{E}-4$

Fiselle $\mathrm{H}_{2} \mathrm{O}$ colution, spheried 8 eometry, $30-\mathrm{cm}$ radius

$1.42 E-4$

Fissile $\mathrm{H}_{2} \mathrm{O}$ eolution, spherical geometry, $50-\mathrm{cm}$ redius

$1.39 E-4$

Fisslle DSO solution, spherical geometry, $2-\mathrm{cm}$ redlus

$1.98 \mathrm{E}-4$

Fissile $D_{2} O$ solution, spherical geometry, $30-\mathrm{cm}$ radius

$6.49 \mathrm{E}-5$

Fiesile $\mathrm{D}_{2} \mathrm{O}$ solution, spherical geomeany, $50-\mathrm{cm}$ radius

6.07E-5

Spectra of fission neutrons through various shielding materials

Fiseion neutrons through $5 \mathrm{~cm}$ of $\mathrm{H}_{2} \mathrm{O}$

$1.4 \mathrm{E}-4$

Fiscion neutrons through $10 \mathrm{~cm}$ of $\mathrm{H}_{2} \mathrm{O}$

$2.06 \mathrm{E}-4$

Fivsion neutrons through $30 \mathrm{~cm}$ of $\mathrm{H}_{2} \mathrm{O}$

$2.72 \mathrm{E}-4$

Fission neutrom through $5 \mathrm{Om}$ of $\mathrm{H}_{2} \mathrm{O}$

$3.97 \mathrm{E}-4$

$1.50 \mathrm{E}-4$

Fission neutrons through $2 \mathrm{~cm}$ of $\mathrm{D}_{2} \mathrm{O}$

$1.82 E-4$

Fission neutrons through $5 \mathrm{~cm}$ of $\mathrm{D}_{2} \mathrm{O}$

Fission neutrons through $10 \mathrm{~cm}$ of $\mathrm{D}_{2} \mathrm{O}$

$7.27 \mathrm{E}-5$

3.71E-5

3.17E-5

$1.66 \mathrm{E}-4$

Fission neutrons through $2 \mathrm{~cm}$ of $D_{2} O$ a surface

$2.45 E-4$

Fission neutrons through $5 \mathrm{~cm}$ of graphite

Fission neutrons through $10 \mathrm{~cm}$ of graphite

Fission neutrons through $20 \mathrm{~cm}$ of graphite

$1.97 \mathrm{E}-4$

$1.03 \mathrm{E}-4$

Fission neutrons through $40 \mathrm{~cm}$ of graphite

2.84E-5

$1.08 \mathrm{E}-5$

Fission neutrons through $60 \mathrm{~cm}$ of graphite

$1.37 \mathrm{E}-4$

Fission neutrons through $10 \mathrm{~cm}$ of polyethylene

Fission nevtrons through $20 \mathrm{~cm}$ of polyethylene

$1.63 \mathrm{E}-4$

Fission neutrons through $40 \mathrm{~cm}$ of polyechylene

$2.28 \mathrm{E}-4$

Fission neutrons through $60 \mathrm{~cm}$ of polyethylene

$2.75 E-4$

$1.65 E-4$

$1.70 \mathrm{E}-4$

Fission neutrons through $10 \mathrm{~cm}$ of $1 \%$ borated polychylene

$2.16 \mathrm{E}-4$

Fission neutrons through $20 \mathrm{~mm}$ of $1 \%$ borated polyethylene

$2.99 \mathrm{E}-4$

Fission neutrons through $40 \mathrm{~cm}$ of $1 \%$ borated polyethylene

$3.51 E-4$

Fission neutrons through $2.5 \mathrm{~cm}$ of beryllium

2.15E-4 
Table 2 (continued)

\begin{tabular}{|c|c|}
\hline Spectrum description & Rutio \\
\hline 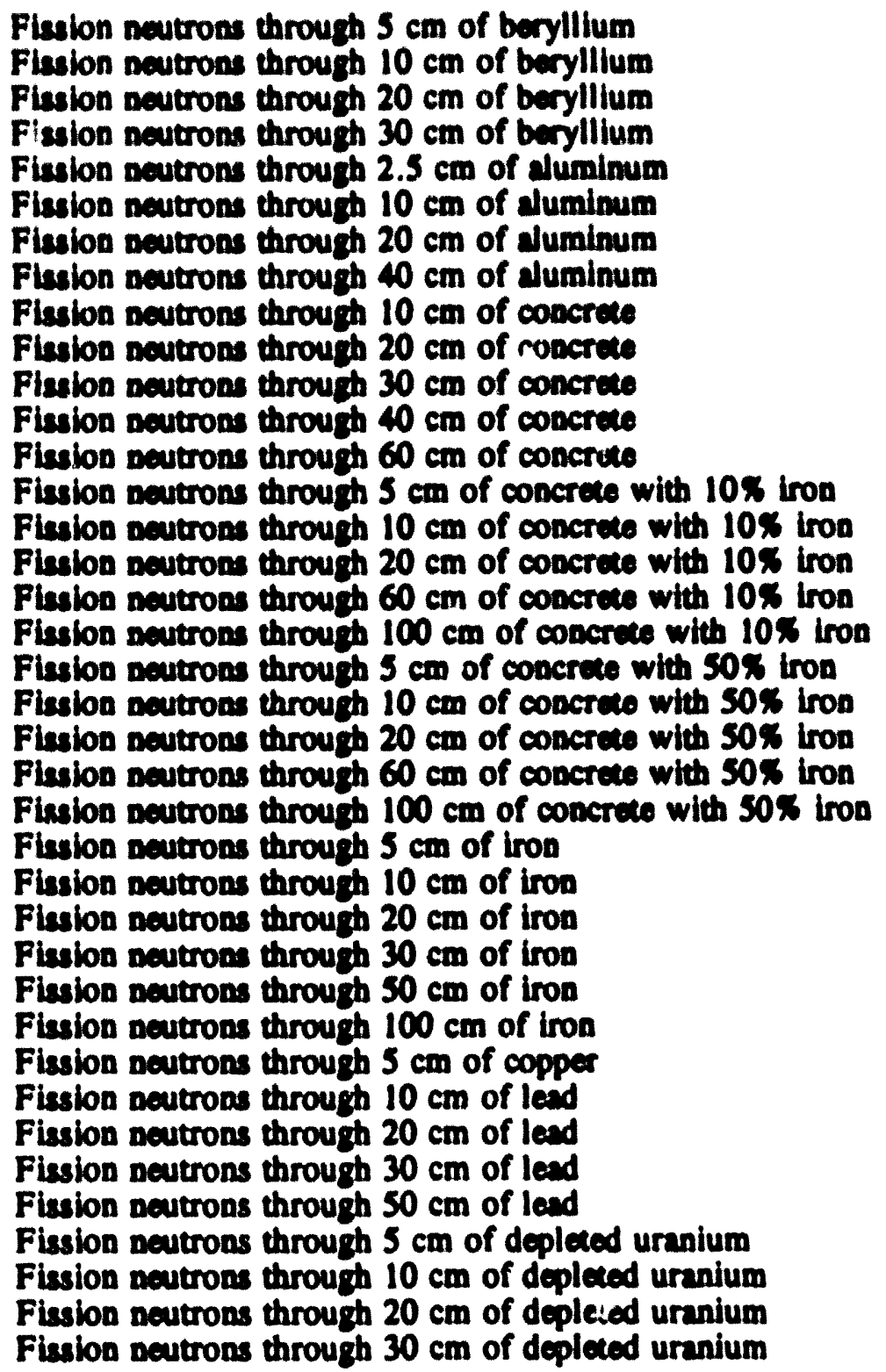 & $\begin{array}{l}1.61 \mathrm{E}-4 \\
7.65 \mathrm{E}-4 \\
2.26 \mathrm{E}-5 \\
8.99 \mathrm{E}-6 \\
2.57 \mathrm{E}-4 \\
1.94 \mathrm{E}-4 \\
1.05 \mathrm{E}-4 \\
2.21 \mathrm{E}-5 \\
1.20 \mathrm{E}-4 \\
7.89 \mathrm{E}-5 \\
5.82 \mathrm{E}-5 \\
5.65 \mathrm{E}-5 \\
5.93 \mathrm{E}-5 \\
2.31 \mathrm{E}-4 \\
1.71 \mathrm{E}-4 \\
1.02 \mathrm{E}-4 \\
5.47 \mathrm{E}-5 \\
4.44 \mathrm{E}-5 \\
2.17 \mathrm{E}-4 \\
1.50 \mathrm{E}-4 \\
7.64 \mathrm{E}-5 \\
2.85 \mathrm{E}-5 \\
2.12 \mathrm{E}-5 \\
1.26 \mathrm{E}-4 \\
6.78 \mathrm{E}-5 \\
1.84 \mathrm{E}-5 \\
4.75 \mathrm{E}-6 \\
2.56 \mathrm{E}-7 \\
8.54 \mathrm{E}-11 \\
1.10 \mathrm{E}-4 \\
1.06 \mathrm{E}-4 \\
3.94 \mathrm{E}-5 \\
1.32 \mathrm{E}-5 \\
1.85 \mathrm{E}-6 \\
1.11 \mathrm{E}-4 \\
5.38 \mathrm{E}-5 \\
1.60 \mathrm{E}-5 \\
6.30 \mathrm{E}-6\end{array}$ \\
\hline
\end{tabular}

Spectra of moderated $\mathrm{H}_{2} \mathrm{O}$ fission neutrons through shielding materials

Moderated $\mathrm{H}_{2} \mathrm{O}$ fission neutrons through $2.5 \mathrm{~cm}$ of beryllium

8.59E-5

Moderated $\mathrm{H}_{2} \mathrm{O}$ fission neutrons through $5 \mathrm{~cm}$ of beryllium

6.95E-5

4.03E-5

1.46E-5

Moderated $\mathrm{H}_{2} \mathrm{O}$ fission neutrons through $20 \mathrm{~cm}$ of beryllium

5.65E-5

Moderated $\mathrm{H}_{2} \mathrm{O}$ fission neutrons through $10 \mathrm{~cm}$ of aluminum

2.67E-5

Moderated $\mathrm{H}_{2} \mathrm{O}$ fission neutrons through $20 \mathrm{~cm}$ of aluminum

6.88E-5

Moderated $\mathrm{H}_{2} \mathrm{O}$ fission aeutrons through $10 \mathrm{~cm}$ of concrete

5.89E-5

Moderated $\mathrm{H}_{2} \mathrm{O}$ fission neutrons through $30 \mathrm{~cm}$ of concrete

S.93E-5 
Table 2 (continued)

\begin{tabular}{lcc}
\hline \multicolumn{1}{c}{ Spectrum description } & Ratio \\
\hline Moderated $\mathrm{H}_{2} \mathrm{O}$ fission neutrons through $20 \mathrm{~cm}$ of iron & $1.09 \mathrm{E}-5$ \\
Moderated $\mathrm{H}_{2} \mathrm{O}$ fission neutrons through $50 \mathrm{~cm}$ of iron & $5.40 \mathrm{E}-7$ \\
Moderated $\mathrm{H}_{2} \mathrm{O}$ fission neutrons through $5 \mathrm{~cm}$ of copper & $5.30 \mathrm{E}-5$ \\
Moderated $\mathrm{H}_{2} \mathrm{O}$ fission neutrons through $10 \mathrm{~cm}$ of copper & $2.77 \mathrm{E}-5$ \\
Moderated $\mathrm{H}_{2} \mathrm{O}$ fission neutrons through $20 \mathrm{~cm}$ of copper & $7.38 \mathrm{E}-6$ \\
Moderated $\mathrm{H}_{2} \mathrm{O}$ fission neutrons through $30 \mathrm{~cm}$ of copper & $1.92 \mathrm{E}-6$ \\
Moderated $\mathrm{H}_{2} \mathrm{O}$ fission neutrons through $50 \mathrm{~cm}$ of copper & $1.16 \mathrm{E}-6$ \\
Moderated $\mathrm{H}_{2} \mathrm{O}$ fission neutrons through $5 \mathrm{~cm}$ of lead & $6.93 \mathrm{E}-5$ \\
Moderated $\mathrm{H}_{2} \mathrm{O}$ fission neutrons through $10 \mathrm{~cm}$ of lead & $4.66 \mathrm{E}-5$ \\
Moderated $\mathrm{H}_{2} \mathrm{O}$ fission neutrons through $30 \mathrm{~cm}$ of lead & $6.69 \mathrm{E}-6$ \\
Moderated $\mathrm{H}_{2} \mathrm{O}$ fission neutrons through $50 \mathrm{~cm}$ of lead & $8.33 \mathrm{E}-7$ \\
& \\
Spectra of fission neutrons from a small $25 \mathrm{Cf}$ source & \\
Fission neutrons from & \\
Doref with no shielding & $2.67 \mathrm{E}-4$ \\
\hline
\end{tabular}

The neutron energy spectra are from tables in the appendices of the report by Ing and Makra, ${ }^{16}$ unless noted otherwise.

See ref. 17.

See ref. 18.

Figures 8 through 12 show plots of $D / A_{N a}$ (the ratio of absorbed dose from neutrons to blood sodium activation) versus $A_{\text {Hari }} / A_{\mathrm{Na}}$ (the ratio of hair sulfur activation to blood sodium activation) from previous studies. ${ }^{14.20}$ In these previous studies, the reciprocal of the ratio of absorbed dose to blood sodium activation was used (i.e., $A_{N a} / D$ ). It needs to be noted that this ratio is now being used directly (i.e., $D / A_{N a}$ ). This make more sense because it emphasizes the very simple fact that both the ratios for absorbed dose $\left(D / A_{N a}\right)$ and hair activation $\left(A_{H a t r} / A_{N a}\right)$ increase in value for more energetic neutron spectra. Figure 8 provides a comparison of data from Feng et al. ${ }^{14}$ with that from Hankins. ${ }^{26}$ The curve on the left summarizes Hankins' data for accidents where thick metal shields or reflectors were present, and the curve on the right summarizes his data for accidents where there were no such shields. If $A_{\mathrm{Har}} / A_{\mathrm{Na}}$ has a value typical of those for a lightly shielded critical assembly (i.e., the value of $A_{H a t} / A_{N a}$ falls in the range of values from $5 \times 10^{-5}$ to $1 \times 10^{-3}$ ), then the procedure for estimating absorbed dose to nel $s$ can : unite simple. ${ }^{26}$ The factor for converting blood sodium activation to absorbed dose trom neutrons is simply read from the graph in Fig. 8. This very simple procedure is 

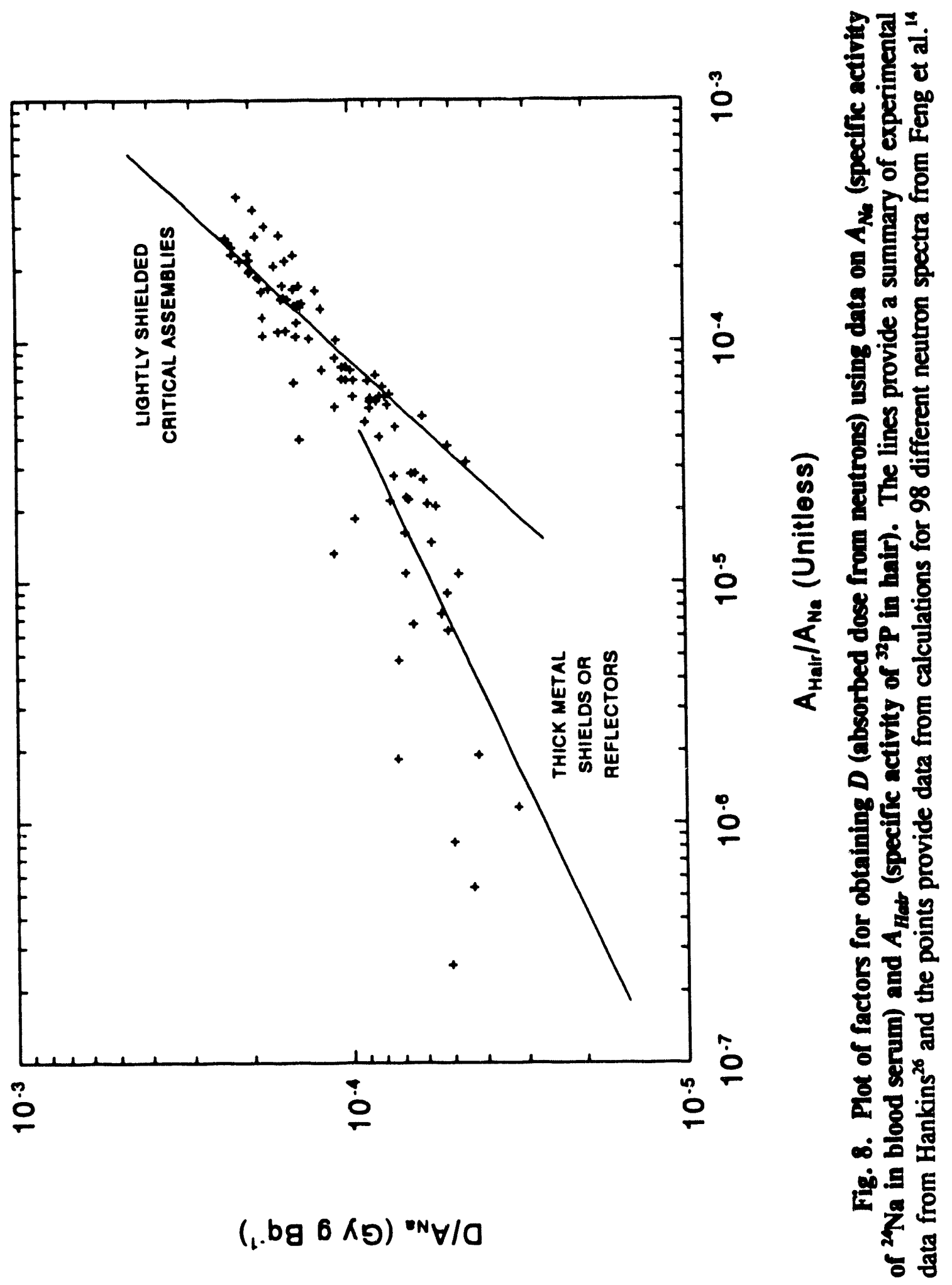
FISSION NEUTRONS FROM CRITICAL SOLUTIONS

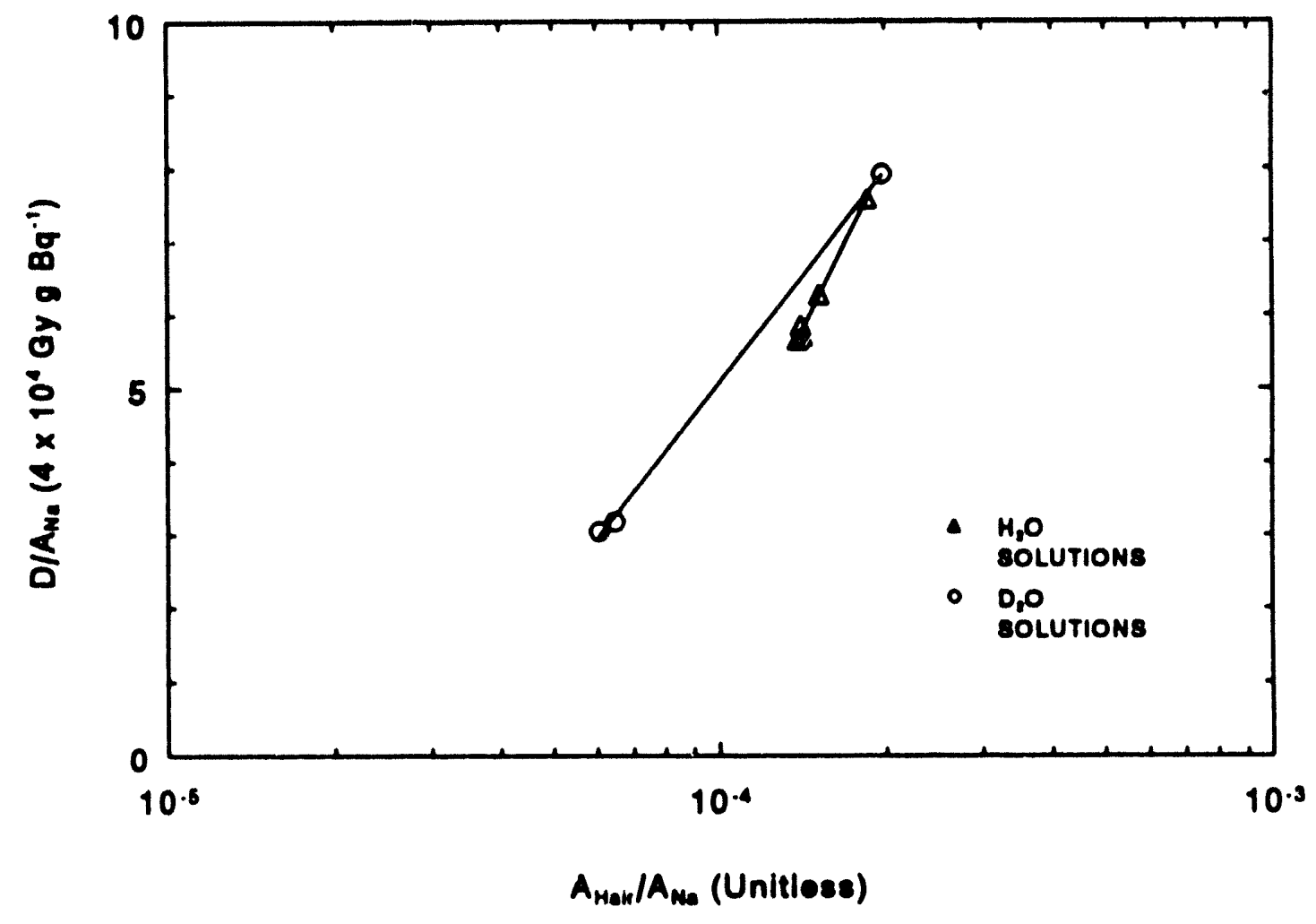

Fis. 9. Plot of data on $D / A_{N_{1}}$ versus $A_{M_{1}} / A_{N_{0}}$ for spectra of fission neutrons from critical $\mathrm{H}_{2} \mathrm{O}$ and $\mathrm{D}_{2} \mathrm{O}$ solutions ${ }^{16}$ (also see Tables 1 and 2 of this report). 
FISSIO: NEUTRONS THAOUGH

VARIOUS SHIELDING MATERIALS
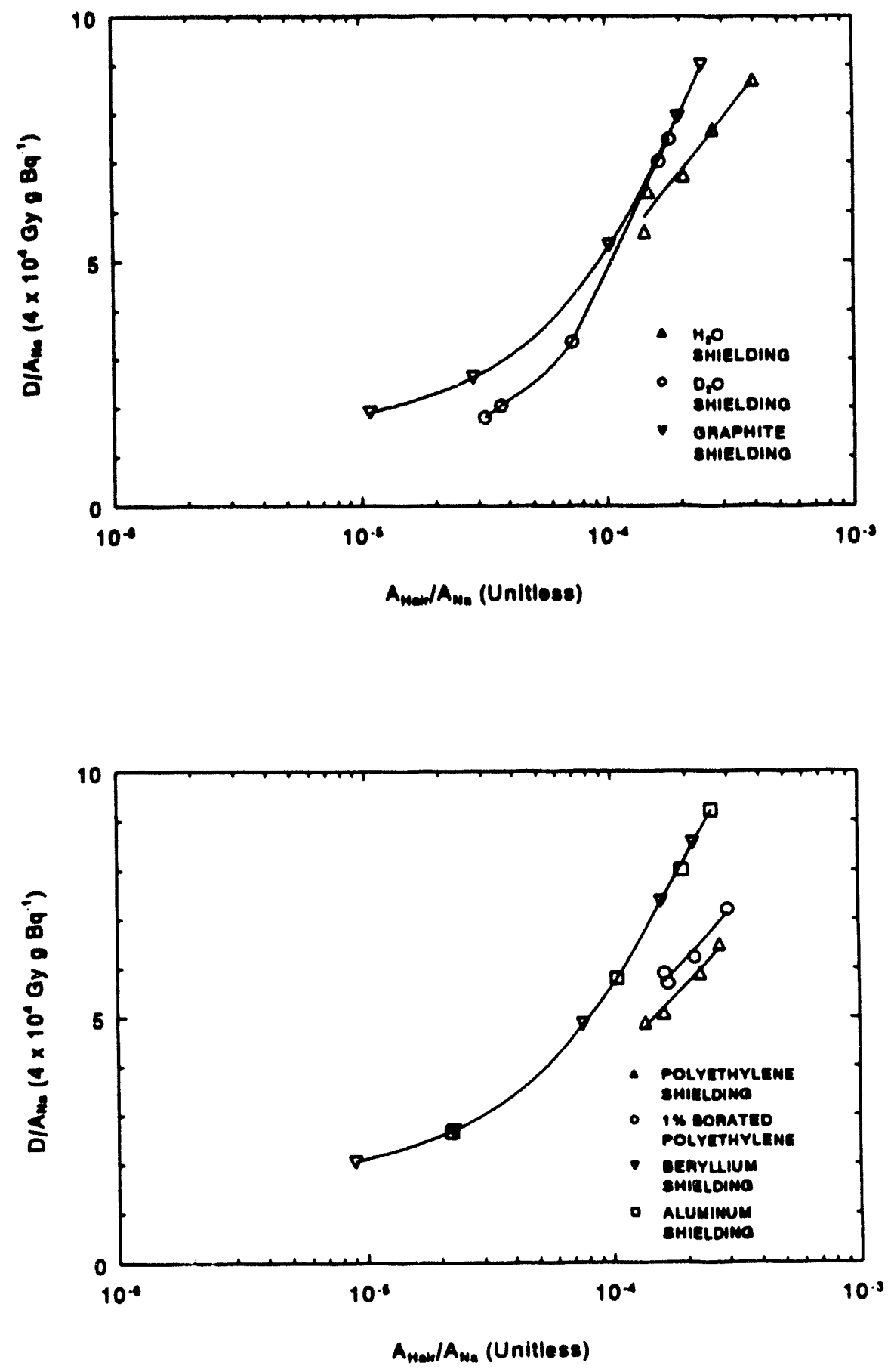

Fig. 10. Plots of data on $D / A_{N e}$ versus $A_{H e w} / A_{N a}$ for spectra of fission neutrons through shielding materials or reflectors of $\mathrm{H}_{2} \mathrm{O}, \mathrm{D}_{2} \mathrm{O}$, graphite, polyethylene, borated polyethylene, beryllium, and aluminum ${ }^{14}$ (also see Tables 1 and 2 of this report). 


\section{FISSION NEUTRONS THROUGH VARIOUS SHIELDING MATERIALS}
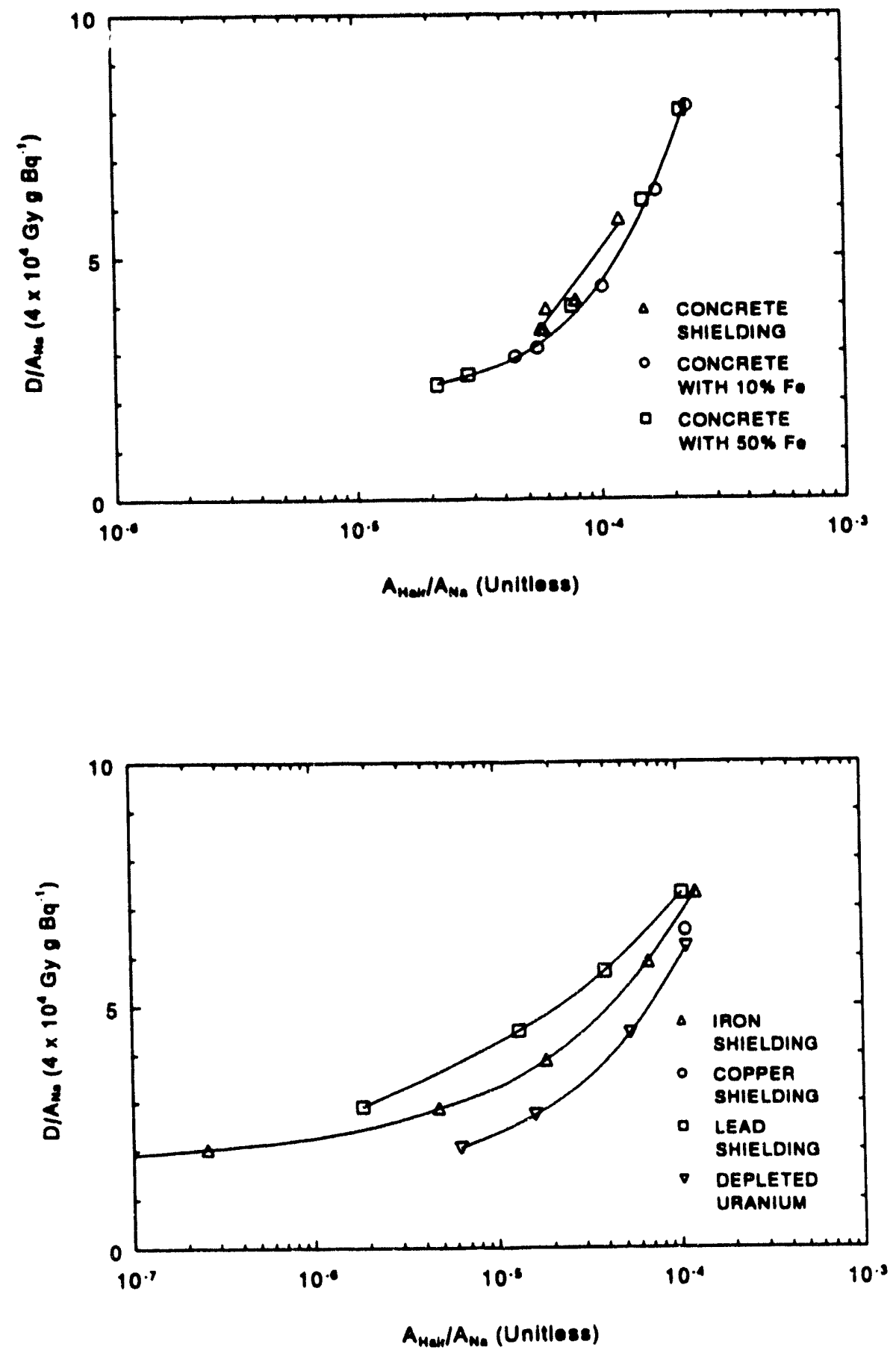

Fig. 11. Plots of data on $D / A_{\mathrm{Na}}$ versus $A_{\mathrm{Haw}} / A_{\mathrm{Na}}$ for spectra of fission neutrons through shielding materials or reflectors of concrete, concrete with iron, iron, copper, lead, and depleted uranium ${ }^{14}$ (also see Tables 1 and 2 of this report). 

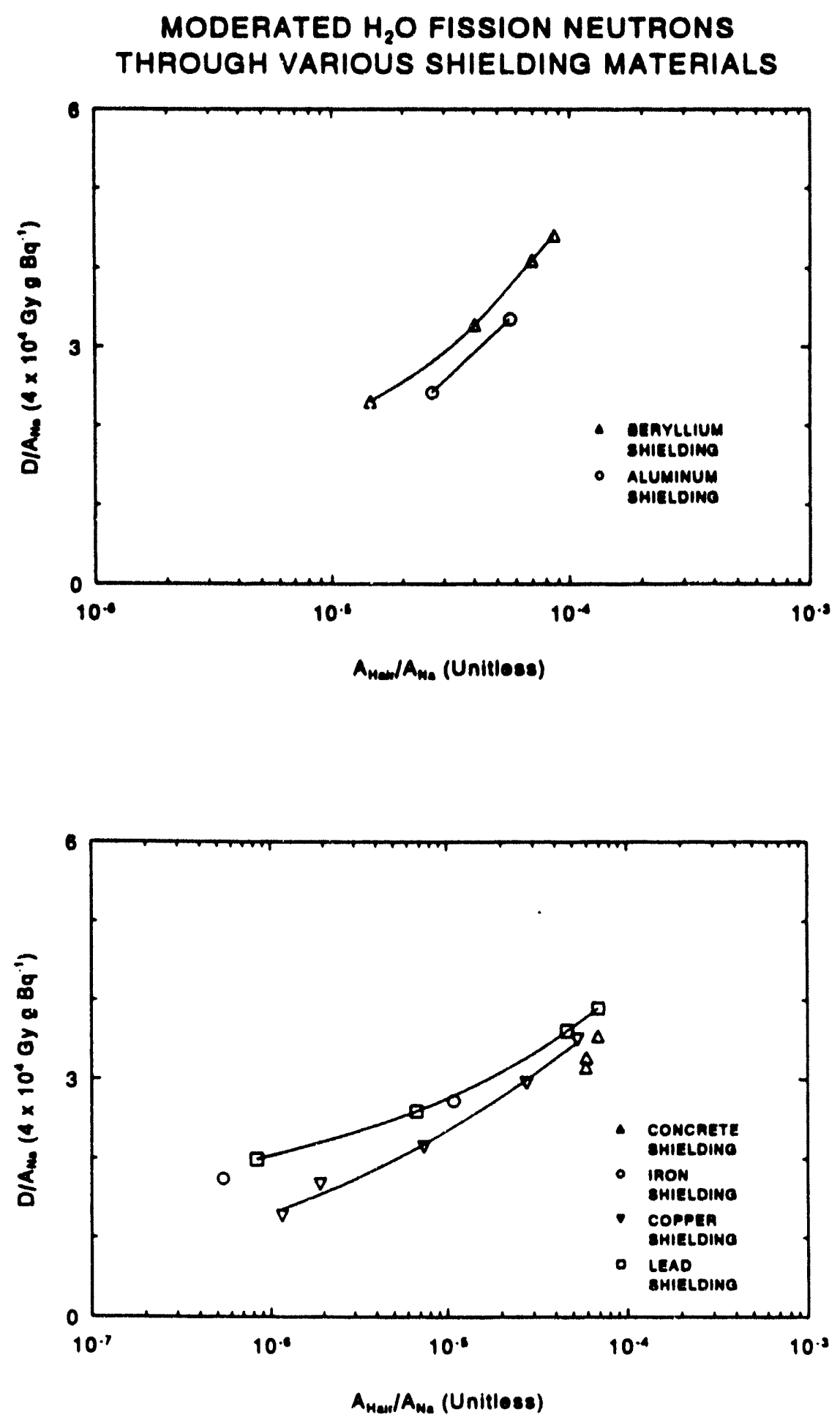

Fig. 12. Plots of data on $D / A_{N_{0}}$ versus $A_{\text {Badr }} / A_{N_{0}}$ for spectra of moderated $\mathrm{H}_{2} \mathrm{O}$ fission neutrons through shielding materials or reflectors of beryllium, aluminum, concrete, iron, copper, and lead ${ }^{14}$ (also see Tables 1 and 2 of this report). 
recommended, however, when the only available information is that on activation of hair and blood. 14 If other information is available for a lighuly shielded critical assembly (i.e., the type and thickness of shielding, etc.) O a critical ussembly with a thick metal shield or reflector is involved (i.e., the value of $A_{\text {matr }} / A_{N_{a}}$ is leas than $5 \times 10^{-5}$ ), then the factor for converting blood sodium activation to absorbed dose from neutrons should be obtained from the graphs in Figs. 9-12 (also see Tables 1 and 2 of this report).

\subsection{PERSONNEL NUCLEAR ACCIDENT DOSDMETERS}

In 1989, a new Centrulized External Dosimetry System (CEDS) was implemented for personnel dosimetry at the following DOE facilities managed by Martin Marietta Energy Systems: ORNL, the Oak Ridge Y-12 Plant, the Oak Ridge K-25 Plant, and the Paducah Gaseous Diffusion Plant. These routinely issued dosimeters will serve as personnel nuclear accident dosimeters (PNADs) following a nuclear accident." Two types of CEDS dosimeters are currently in use: (1) a blue $\beta-\gamma$ dosimeter, and (2) the red neutron dosimeter. These CEDS dosimeters are based on Harshaw/Filtrol thermoluminescent detectors, TLD-600 and TLD-700. TLD-700 is the LiF-TLD with ' $\mathrm{Li}$ enriched to 99.93\%, and TLD-600 is the LiF-TLD with ' $L i$ enriched to 95.62\%. The TLD-600 is neutron-sensitive with a response mostly in the lowenergy and thermal region of the neutron spectrum. The TLD-700 is relatively insensitive to neutrons of any energy.

Filtration for the $\beta-\gamma$ dosimeter includes one $1-g / \mathrm{cm}^{2}$ tissue-equivalent filter, one copper filter, and one thin Mylar window for beta transmission, over each of three TLD-700 detectors; and one $300-\mathrm{mg} / \mathrm{cm}^{2}$ filter, over a TLD-600 detoctor, as shown in Fig. 13 (ref. 27). Application of a complex algorithm allows separation of radiation doses from beta particles, photons, and neutrons, and allows some photon discrimination for low-energy $X$ mys. The neutron dosimeter has one TLD-600/TLD-700 pair mounted under $300 \mathrm{mg} / \mathrm{cm}^{2}$ of plastic, and one TLD-600/ TLD-700 pair mounted under a cadmium filter as shown in Fig. 14 (ref. 27). This allows discrimination against incident thermal neutrons, to which the TL.D-600 characteristically overresponds. The readout and calibration of these dosimeters is a complex process. Corrections are made for both the individual response of the various TLD elements of each 


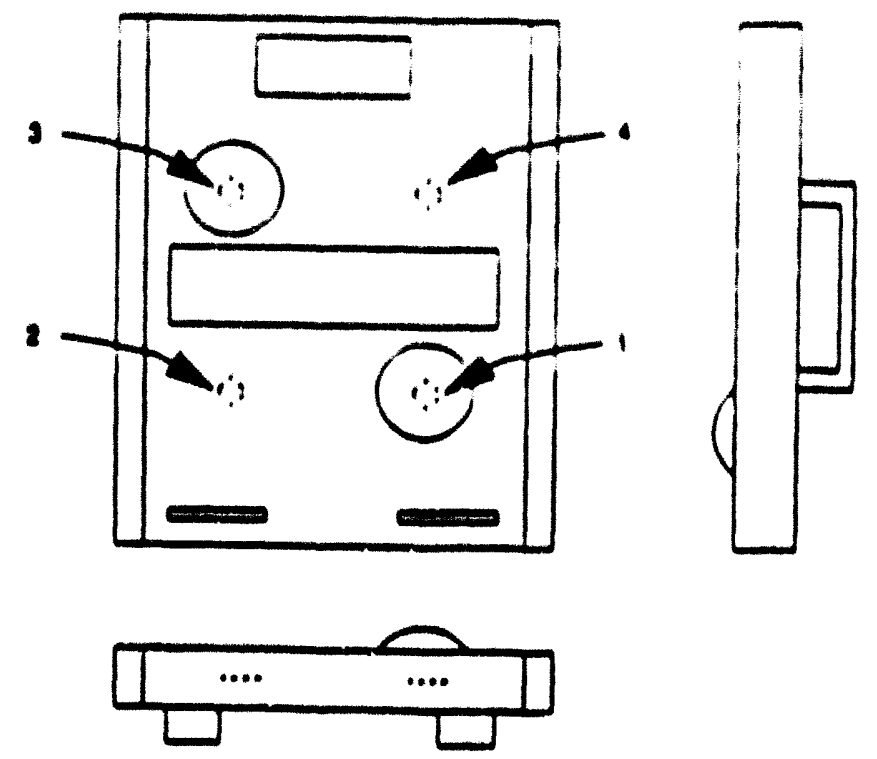

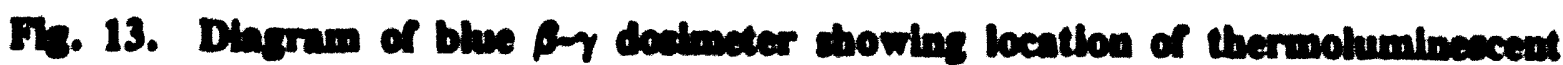

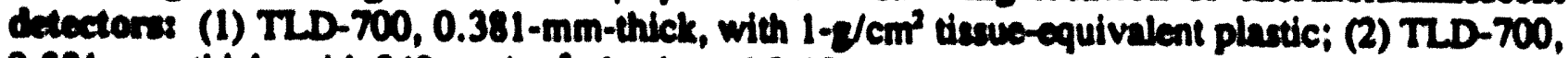
$0.381-\mathrm{mm}$-thick, with 242-me/ $\mathrm{cm}^{2}$ plestic and 0.10-mm copper filter; (3) TLD-700, 0.090- $\mathrm{mm}$ thick, with Mylar-covered open window $\left(7.5 \mathrm{mg} / \mathrm{cm}^{2}\right)$; and (4) TLD-600, 0.381-mm-thick, with $300-\mathrm{mg} / \mathrm{cm}^{2}$ tisere-equivilent plastic.
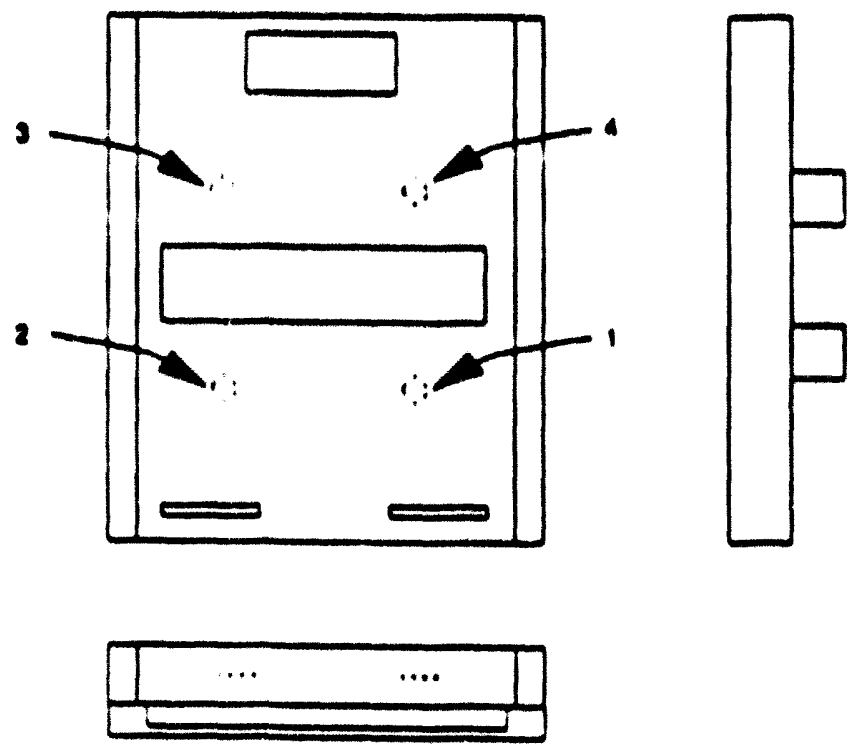

Fis. 14. Diagram of red neutron doclmeter showing location of thermoluminescent detectors: (1) TL.D-600, $0.381-\mathrm{mm}$-thick, with $70-\mathrm{mg}_{\mathrm{g}} / \mathrm{cm}^{2}$ plastic and $0.46-\mathrm{mm}$ cadmium filler; (2) TLD-700, $0.381-\mathrm{mm}$-thick, with $70-\mathrm{mg} / \mathrm{cm}^{2}$ plastic and $0.46-\mathrm{mm}$ cadmium filter; (3) TLD-700, 0.381-mm-thick, with $300-\mathrm{mg} / \mathrm{cm}^{2}$ plastic; and (4) TLD-600, $0.381-\mathrm{mm}$-thick, with $300-\mathrm{mg} / \mathrm{cm}^{2}$ plastic. 
dosimeter and the reaponse of the TLD reader as well as the application of a dose calibration correction factor and a spectral correction factor for neutrons."

For nuclear socident dodimetry, it is necceany to limit the output of the reader from very high-dose readings. This was done by using a $1 \%$ of a $10 \%$ attenuator between the TLD and photomuldplier of the Harchaw/Filtrol Model 8800 TLD reader. Results from the readout of the B-y dotimeter will normally be used to evaluate the eamma-nay and neutron doses. However, if an exposed individual is wearing the neutron dosimeter, then the cadmium-covered TID elements of this dodimeter will be used to evaluate the neutron dose. The neutron readings will be corrected by applying both a spectrd correction fector and a dose calibration factor as discused in the next section (Sect. 3.5).

It needs to be noted that a PNAD may not provide a reliable estimate for neutron dose if a person was nol facing directly loward the source. Responses of CEDS neutron dosimeters 10 \& ${ }^{212} \mathrm{C}$ s source with incident angles ocher than sero vary from a few percent smaller $1080 \%$ emaller than that from a perpendicular irradiation." A person's orientation is also needed to make a reliable PNAD eatimate of the gamma-ny dowe but the requirements on orientation are leas atringent. Figure 15 shows the sbeorted dose from gamma nys at the front surface of the body for a person facing loward the cource (i.e., a so-called A-P exposure) and a person facing away from the source (i.e., a so-called P-A exposure) as calculated by Enz and Murphy." When a broad enerzy spectrum of eamma rays is involved, the absorbed dose as determined by the reading of element $/ 1$ in the $\beta-\gamma$ dosimeter will be underestimated by about $50 \%$ if the person is facing away from the source (i.e., a P-A exposure) and $20 \%$ if the person is standing sideways with respect to the source (i.e., a lateral exposure). Hence, the PNAD estimate for the gamma-ray dose should be adjusted accordingly using the best available information on a person's orientation during their exposure period.

\subsection{FTXED NUCLEAR ACCDENT DOSIMETERS}

Figure 16 shows a fixed nuclear accident dosimeter (FNAD) which is a combination of the two CEDS dosimeters mounted on a small phantom of Lucite (manufactured by the DuPont Corporation). The phantom is needed to assure the proper neutron-albedo response for the matched TLD-600/TLD-700 pairs in the two CEDS dosimeters." To enhance the albedo 


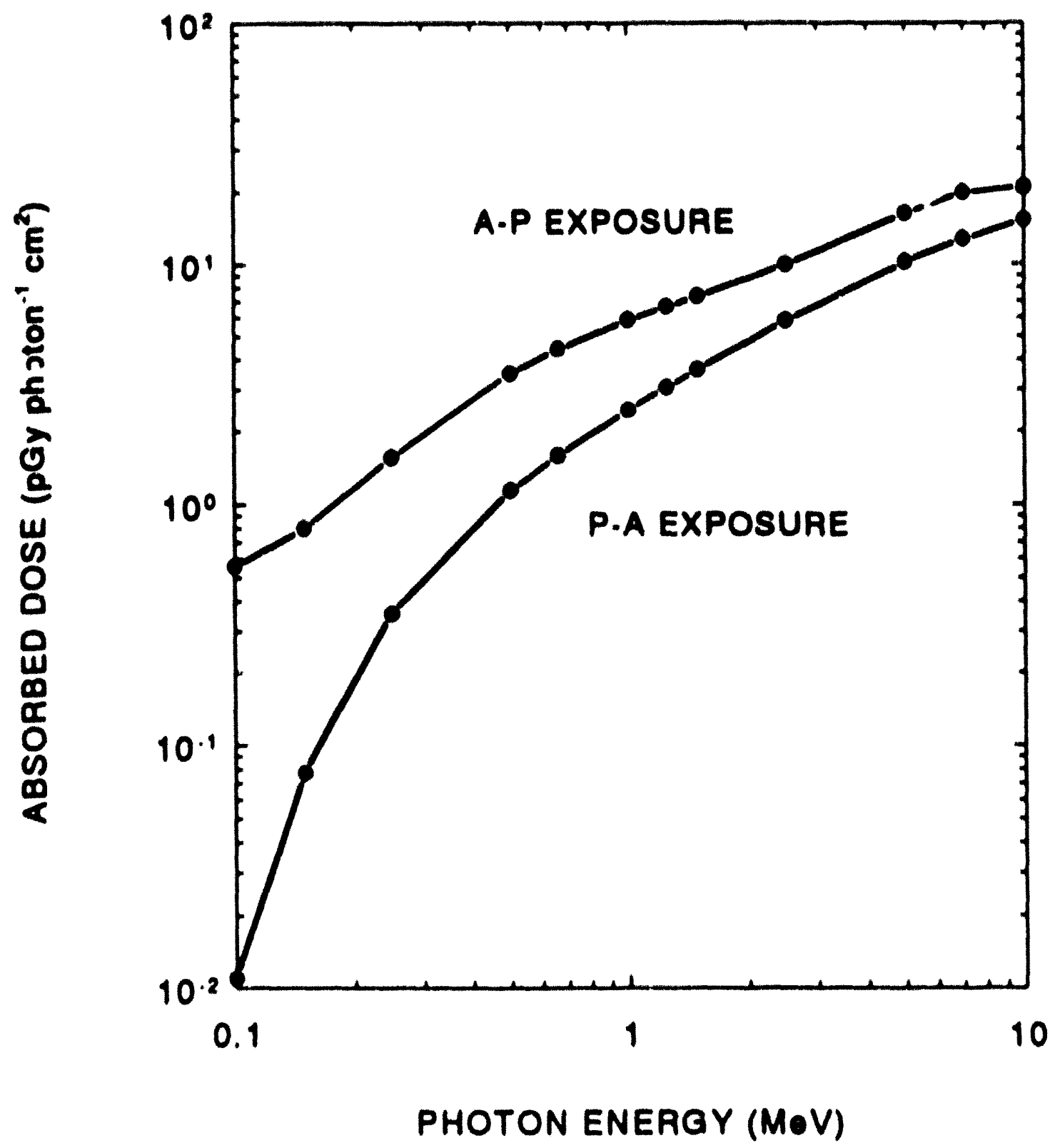

F3. 15. Absorbed doce from gamma rays at the front surface of the body for a person facing the source (I.e., a so-called A-P exposure) and a person facing away from the source (l.e., a so-called P.A exposure) as calculated by Enz and Murphy." 


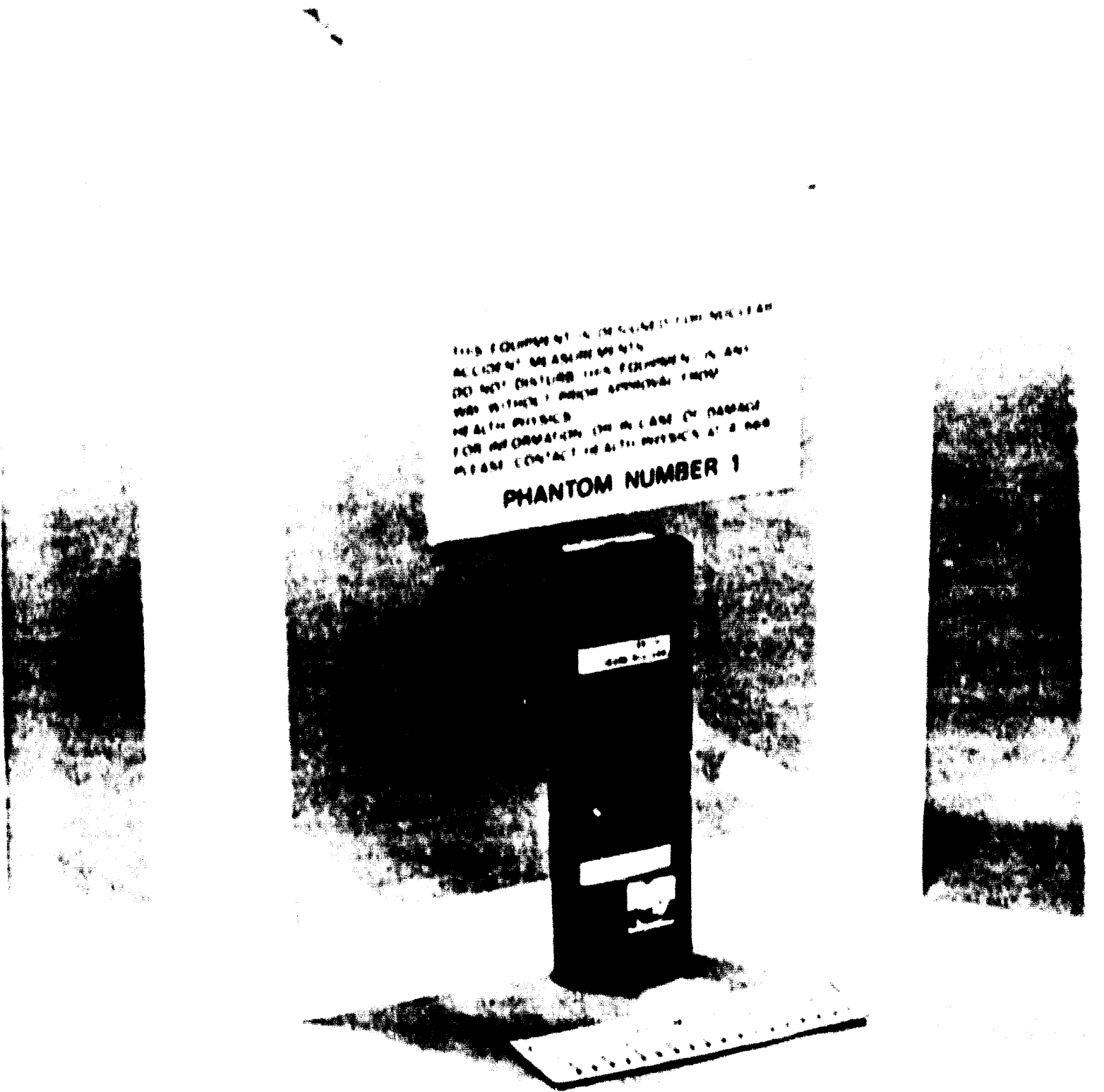

Fis. 16. Photosiaph showing a FNAD whlch consists of iwo personnel dosimeters mounted on a mall $20 \times 20 \times 10 \mathrm{~cm}$ phantom. The neutron dosimeter (located at the center of the phantom) is shown in Fig. 14, and $\beta \cdot \gamma$ dosimeter (locatod loward the bottom of the phantom) is shown in Fig. 13. There are two mounting holes at the boltom of the phantom so that it can be used to attached to a wall with the dosimeters facing in the general direction of the potential sources for a nuclear criticality accident. 
response, the dosimeters should also be tight againat the phantom and oriented toward the source." Thus, the lixpps have been removed from the back of the two dosimeters and the FNADs have been pusidioned with the two dosimeters facing in the general direction of the potential sources for a nuclear criticality eccident.

Readings of the $\beta-\gamma$ dosimeter will be used to evaluate the gamma-ray dose, and readings of the cadmium-covered TLDs of the neutron dosimeter will be used to evaluate the neutron dose. ${ }^{n}$ The formula for evaluation of the gamma-nay dose is:

$$
D_{1}=A \times C F_{Y} \text {. }
$$

where $D$ is the absorbed dose in $O y$ (or nd), $A$ is the output of the TLD reader for element $\| 1$ of the $\beta-\gamma$ dosimeter in nanocoulomb $(n C)$, and $C F$ is the calibration factor in $O y$ per $n C$ (or nad per $n C$ ). Evaluntion of the neutron dose is more difficult because of the severe energydependent response of a neutron albedo dotimeter." The formula for evaluation of the neutron dose is:

$$
D_{1} \cdot\left(\frac{B_{1} \times \Delta C C_{1}}{R C F_{1}}-\frac{D_{2} \times \Delta C C_{2}}{R C F_{2}}\right) \times S C \times S F
$$

where $B_{1}$ is the output of the TLD reader for element $\| 1$ and $B_{2}$ is the output of the TLD reader for element $\boldsymbol{R}$ of the neutron dosimeter, $E C C_{1}$ and $E C C_{2}$ are the corresponding element correction coefficients, $R C F_{1}$ and $R C F_{2}$ are the reader calibration factors for the two positions, $S C$ is the factor for converting the equivalent gamma-nay exposure to absorbed dose from the $D_{2} O-$ moderated ${ }^{22} \mathrm{Cf}$ calibration source, and $S F$ is the spectral conversion factor. The spectral conversion factor is calculated as follows:

$$
S P=\left(D_{0.1} \times R_{2}\right) /\left(D_{0,2} \times R_{1}\right)
$$

where $D_{n, 1}$ is the absorbed dose for the neutron energy spectrum of interest, $D_{n, 2}$ is the absorbed dose for the neutron energy spectrum of the $D_{2} O-$ moderated ${ }^{232} \mathrm{Cf}$ calibration source, and $R_{1}$ and $R_{2}$ are the corresponding dosimeter responses. The same conversion-factor and neutron-dose 
calculations can be performed for the non-cadmium covered TLD pair of the neutron dosimeter (i.e., elements 13 and (14). Table 3 gives spectral conversion factors for both non-cadmium and cadmium covered TLD pains from calculations for over 100 different neutron spectra.

To ensure that the CEDS TLD-baced dosimeters meet the general requirements for nuclear socident dosimetry, several steps were taken: (1) The dosimeters were tested for neutron and gamma ndiations across the range required to ensure that the response was adequate and the errors in the measurements were within the required limits. A ${ }^{13} \mathrm{Cs}$ gamma-ray source and - ${ }^{22} \mathrm{Cf}$ neutron source were used to test the dosimeters at socident-level doses near $0.005,0.01$, $0.05,0.1,0.5,1,5$, and $10 \mathrm{Oy}$. The results are shown in Fig. 17 through 19 (ref. 27). These results indicate that neutron doses can be measured $10 \pm 30 \%$ and gamma-ray doses can be measured to $\pm 20 \%$ except at the higheas doses, near $10 \mathrm{~Gy}(1000 \mathrm{rd})$. The overresponse at very high doses is mostly attributable to the well-known supralinearity of the TLD. (2) The spectral correction factors for different neutron spectn expected in a nuclear accident were made available to CEDS operitors. To asciat these operntors, a computer code, PNADXPC, was developed with a menu that allows the CEDS operator to choose the neutron spectrum for use with each $\beta-\gamma$ dosimeter. Truining also has been provided for the CEDS operators to ensure that they understand these newer system functions for socident-level dosimetry. (3) The neutron responses of the dosimeters were tested at the Army Pulse Reactor Facility (i.e., Aberdeen Reactor), which can be used to simulate a nuclear accident situation. ${ }^{n}$ The neutron response of the neutron dosimeter was evaluated using Eq. (4), and the neutron response of the $\beta$ - $\gamma$ dosimeter was evaluated using the equation:

$$
D_{1}=\left(\frac{B_{1} \times E C C_{4}}{R C F_{4}}-\frac{B_{1} \times E C C_{1}}{R C F_{1}}\right) \times S C \times S F \text {. }
$$

where $B$, and $B$, are the outputs of the TLD reader for elements $\| I$ and $\| 4$ of the $\beta-\gamma$ dosimeter, $E C C_{1}$ and $E C C_{4}$ are the corresponding element corroction coefficients, $R C F$, and $R C F$, are the reader calibration factors for the two positions, SC is the source conversion factor as defined previously, and SF is the spectral conversion factor for a non-cadmium covered TLD pair from Table 3. 
Table 3. Spectral correction factor (SF) for matched TLD-600/TLD-700 pairs with and without cadmium covers (or fiters)"

\begin{tabular}{ccc}
\hline Spectrum deacriptiour & No Cd & Cd \\
fllier & fllter \\
\hline
\end{tabular}

Spectra of fision neutron from solected critical asemblies

Uncollided fiesion spectrum

HPRR spectrum a $3 \mathrm{~m}$ with no shialding

HPRR epectrum a $3 \mathrm{~m}$ with $12 \mathrm{~cm}$ of Lucite shlolding

HPRR epectrum a $3 \mathrm{~m}$ with $13 \mathrm{~cm}$ of neol childing

Aberdew Reector spectrum of $1.5 \mathrm{~m}$ with no shidding

Aberdesen Resctor spectrum an 3 in with no shiolding

Aberdecen Resctor spectrum at $9 \mathrm{~m}$ with no chiolding

Combination HPRR and Aberdeen Reactor spectruma

SHEBA Reactor spectrum-a solution critical assembly
HPRR epectrum a $3 \mathrm{~m}$ with $20 \mathrm{~cm}$ of concrete shielding

7.20

3.61

1.71

2.63

1.58

4.69

4.42

3.81

3.41

2.17

4.90

3.98

3.43

3.24

3.20

6.05

4.57

3.01

1.73

1.42

Fissile D,O solution, spherical seometry, $50-\mathrm{cm}$ radius
7.09

3.61

1.91

2.61

1.69

4.58

4.30

3.70

3.66

2.50

Spectra of fission neutrons through various shidding materials

Fission neutrons through $2 \mathrm{~cm}$ of $\mathrm{H}_{2} \mathrm{O}$

4.96

4.88

Fission neutrons through $5 \mathrm{~cm}$ of $\mathrm{H}_{2} \mathrm{O}$

3.46

3.47

Fission neutrons through $10 \mathrm{~cm}$ of $\mathrm{H}_{2} \mathrm{O}$

3.71

3.68

Fiesion neutrons through $30 \mathrm{~cm}$ of $\mathrm{H}_{2} \mathrm{O}$

2.34

2.35

Fission deutrons through $5 \mathrm{O} \mathrm{cm}$ of $\mathrm{H}_{2} \mathrm{O}$

5.37

Fission peutrons through $2 \mathrm{~cm}$ of $\mathrm{H}_{2} \mathrm{O}$ at surface

4.42

3.33

Fission neutrons through $2 \mathrm{~cm}$ of $\mathrm{D}_{2} \mathrm{O}$

5.72

4.35

Fission neutrons through $5 \mathrm{~cm}$ of $\mathrm{D}_{2} \mathrm{O}$

1.87

5.59

Fission neutrons through $10 \mathrm{~cm}$ of $\mathrm{D}_{2} \mathrm{O}$

0.76

1.84

Fission neutrons through $30 \mathrm{~cm}$ of $\mathrm{D}: O$

0.61

0.76

Fission noutrons through $50 \mathrm{~cm}$ of $\mathrm{D}_{3} \mathrm{O}$

0.55

Fission neutrons through $2 \mathrm{~cm}$ of $D_{2} O$ at surface

5.32

6.24

0.62

Fission neutrons through $5 \mathrm{~cm}$ of graphice

Fission neutrons through $10 \mathrm{~cm}$ of graphice

Fission neutrons through $20 \mathrm{~cm}$ of graphite

7.47

0.56

Fission neutrons through $40 \mathrm{~cm}$ of graphite

Fission neutrons through $60 \mathrm{~cm}$ of graphite

3.10

5.20

6.10

7.33

0.81

3.05

0.31

1.01

Fission neutrons through $5 \mathrm{~cm}$ of polyethylene

2.05

0.49

Fission neutrons through $10 \mathrm{~cm}$ of polyethylene

1.01

2.49

Fission neutrons through $20 \mathrm{~cm}$ of polyechylene

Fission neutrons through $40 \mathrm{~cm}$ of polyechylene

0.72

1.50

0.85

1.18

1.40 
Table 3 (continued)

\begin{tabular}{|c|c|c|}
\hline Spectrum descriptior & $\begin{array}{c}\text { No Cd } \\
\text { filter }\end{array}$ & $\underset{\text { filter }}{\text { Cd }}$ \\
\hline 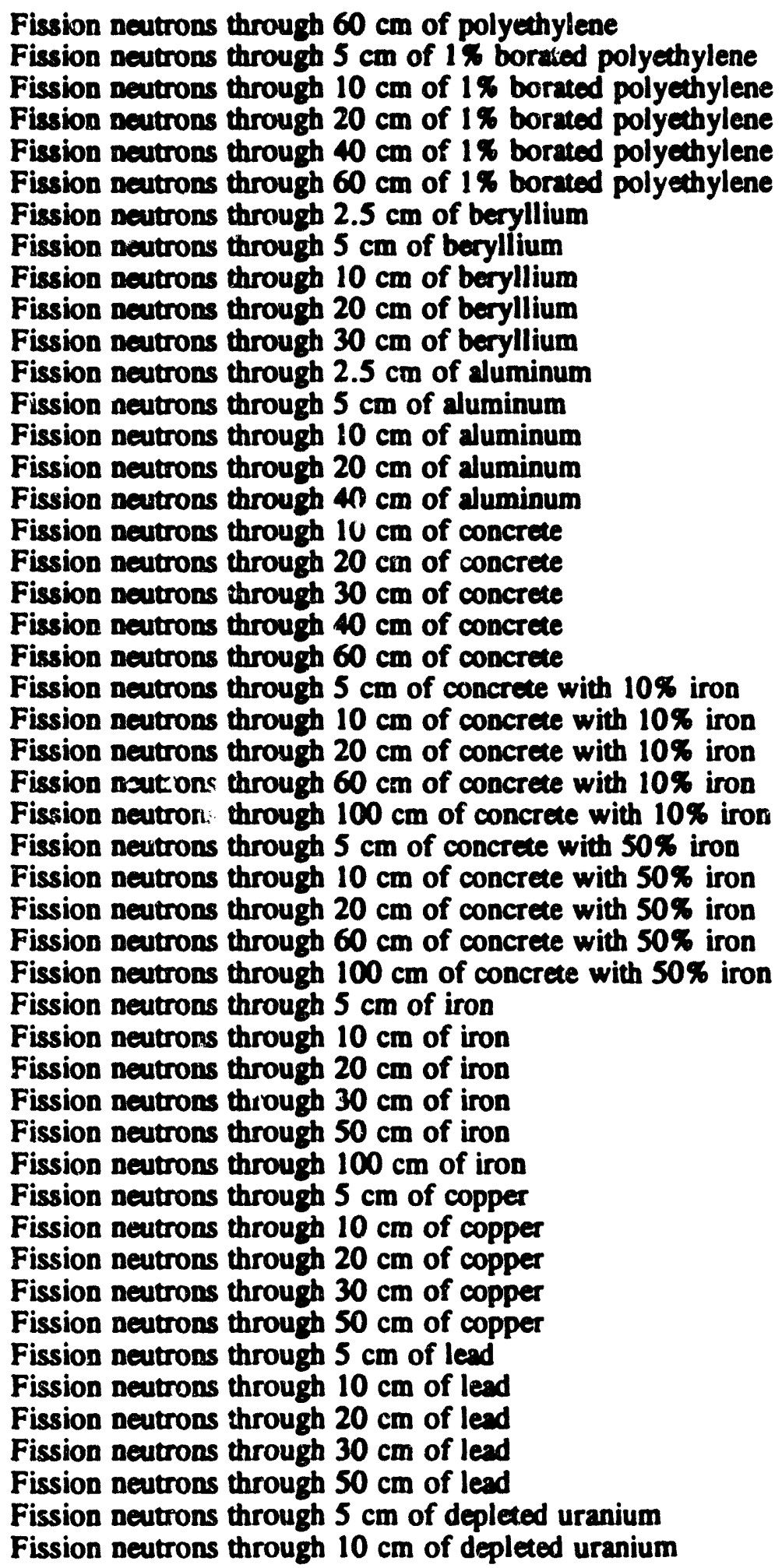 & $\begin{array}{l}1.15 \\
3.45 \\
3.46 \\
5.51 \\
4.14 \\
4.58 \\
6.65 \\
5.55 \\
2.39 \\
0.75 \\
0.29 \\
7.30 \\
7.03 \\
6.23 \\
4.42 \\
2.01 \\
3.81 \\
2.07 \\
1.53 \\
1.46 \\
1.64 \\
5.98 \\
3.84 \\
1.54 \\
0.70 \\
0.39 \\
5.98 \\
3.44 \\
0.91 \\
0.79 \\
0.69 \\
5.68 \\
4.57 \\
3.13 \\
2.39 \\
1.84 \\
0.60 \\
5.09 \\
3.70 \\
2.20 \\
1.48 \\
1.10 \\
6.44 \\
5.75 \\
4.54 \\
3.65 \\
2.44 \\
4.79 \\
3.50\end{array}$ & $\begin{array}{l}1.80 \\
3.46 \\
3.50 \\
5.55 \\
4.17 \\
4.60 \\
6.53 \\
5.44 \\
2.41 \\
0.98 \\
0.48 \\
7.18 \\
6.92 \\
6.12 \\
4.32 \\
1.97 \\
3.75 \\
2.05 \\
1.53 \\
1.46 \\
1.64 \\
5.88 \\
3.91 \\
1.85 \\
1.11 \\
0.65 \\
5.87 \\
3.41 \\
1.30 \\
0.96 \\
0.86 \\
5.58 \\
4.47 \\
3.03 \\
2.31 \\
1.77 \\
0.60 \\
4.99 \\
3.60 \\
2.13 \\
1.44 \\
1.07 \\
6.34 \\
5.65 \\
4.45 \\
3.56 \\
2.36 \\
4.68 \\
3.39\end{array}$ \\
\hline
\end{tabular}


Table 3 (continued)

\begin{tabular}{|c|c|c|}
\hline Spectrum description & $\begin{array}{l}\text { No Cd } \\
\text { filter }\end{array}$ & $\begin{array}{c}\text { Cd } \\
\text { filter }\end{array}$ \\
\hline $\begin{array}{l}\text { Fission neutrons through } 20 \mathrm{~cm} \text { of depleted uranium } \\
\text { Fission neutrons through } 30 \mathrm{~cm} \text { of depleted uranium } \\
\text { Fission neutrons through } 50 \mathrm{~cm} \text { of depleted uranium }\end{array}$ & $\begin{array}{l}2.66 \\
1.76 \\
1.38\end{array}$ & $\begin{array}{l}2.56 \\
1.68 \\
1.32\end{array}$ \\
\hline \multicolumn{3}{|l|}{ Spectra of moderated $\mathrm{H}_{2} \mathrm{O}$ fission neutrons through shielding materials } \\
\hline $\begin{array}{l}\text { Moderated } \mathrm{H}_{2} \mathrm{O} \text { fission neutrons through } 2.5 \mathrm{~cm} \text { of beryllium } \\
\text { Moderated } \mathrm{H}_{2} \mathrm{O} \text { fission neutrons through } 5 \mathrm{~cm} \text { of beryllium } \\
\text { Moderated } \mathrm{H}_{2} \mathrm{O} \text { fission neutrons through } 10 \mathrm{~cm} \text { of beryllium } \\
\text { Moderated } \mathrm{H}_{2} \mathrm{O} \text { fission neutrons through } 20 \mathrm{~cm} \text { of beryllium } \\
\text { Moderated } \mathrm{H}_{2} \mathrm{O} \text { fission neutrons through } 2.5 \mathrm{~cm} \text { of aluminum } \\
\text { Moderated } \mathrm{H}_{2} \mathrm{O} \text { fission neutrons through } 10 \mathrm{~cm} \text { of aluminum } \\
\text { Moderated } \mathrm{H}_{2} \mathrm{O} \text { fission neutrons through } 20 \mathrm{~cm} \text { of aluminum } \\
\text { Moderated } \mathrm{H}_{2} \mathrm{O} \text { fission neutrons through } 10 \mathrm{~cm} \text { of concrete } \\
\text { Moderated } \mathrm{H}_{2} \mathrm{O} \text { fission neutrons through } 20 \mathrm{~cm} \text { of concrete } \\
\text { Moderated } \mathrm{H}_{2} \mathrm{O} \text { fission neutrons through } 30 \mathrm{~cm} \text { of concrete } \\
\text { Moderated } \mathrm{H}_{2} \mathrm{O} \text { fission neutrons through } 40 \mathrm{~cm} \text { of concrete } \\
\text { Moderated } \mathrm{H}_{2} \mathrm{O} \text { fission neutrons through } 60 \mathrm{~cm} \text { of concrete } \\
\text { Moderated } \mathrm{H}_{2} \mathrm{O} \text { fission neutrons through } 2 \mathrm{~cm} \text { of iron } \\
\text { Moderated } \mathrm{H}_{2} \mathrm{O} \text { fission neutrons through } 20 \mathrm{~cm} \text { of iron } \\
\text { Moderated } \mathrm{H}_{2} \mathrm{O} \text { fission neutrons through } 50 \mathrm{~cm} \text { of iron } \\
\text { Moderated } \mathrm{H}_{2} \mathrm{O} \text { fission neutrons through } 5 \mathrm{~cm} \text { of copper } \\
\text { Moderated } \mathrm{H}_{2} \mathrm{O} \text { fission neutrons through } 10 \mathrm{~cm} \text { of copper } \\
\text { Moderated } \mathrm{H}_{2} \mathrm{O} \text { fission neutrons through } 20 \mathrm{~cm} \text { of copper } \\
\text { Moderated } \mathrm{H}_{2} \mathrm{O} \text { fission neutrons through } 30 \mathrm{~cm} \text { of copper } \\
\text { Moderated } \mathrm{H}_{2} \mathrm{O} \text { fission neutrons through } 50 \mathrm{~cm} \text { of copper } \\
\text { Moderated } \mathrm{H}_{2} \mathrm{O} \text { fission neutrons through } 5 \mathrm{~cm} \text { of lead } \\
\text { Moderated } \mathrm{H}_{2} \mathrm{O} \text { fission neutrons through } 10 \mathrm{~cm} \text { of lead } \\
\text { Moderated } \mathrm{H}_{2} \mathrm{O} \text { fission neutrons through } 30 \mathrm{~cm} \text { of lead } \\
\text { Moderated } \mathrm{H}_{2} \mathrm{O} \text { fission neutrons through } 50 \mathrm{~cm} \text { of lead }\end{array}$ & $\begin{array}{l}0.44 \\
1.28 \\
0.88 \\
0.37 \\
1.33 \\
1.26 \\
0.93 \\
1.04 \\
1.65 \\
1.33 \\
1.31 \\
1.72 \\
1.04 \\
1.87 \\
1.88 \\
1.21 \\
2.14 \\
1.70 \\
1.51 \\
1.22 \\
0.77 \\
1.98 \\
1.65 \\
1.49 \\
1.22\end{array}$ & $\begin{array}{l}0.76 \\
1.66 \\
1.20 \\
0.59 \\
1.58 \\
1.51 \\
1.05 \\
1.14 \\
1.64 \\
1.33 \\
1.32 \\
1.72 \\
1.05 \\
1.86 \\
1.84 \\
1.19 \\
2.12 \\
1.67 \\
1.48 \\
1.19 \\
0.76 \\
1.97 \\
1.63 \\
1.48 \\
1.20\end{array}$ \\
\hline \multicolumn{3}{|l|}{ Spectra of fission neutrons from a small ${ }^{252} \mathrm{Cf}$ source } \\
\hline $\begin{array}{l}\text { Fission neutrons from }{ }^{252} \mathrm{Cf} \text { with no shielding } \\
\mathrm{D}_{2} \mathrm{O} \text {-moderated fission neutrons from }{ }^{25} \mathrm{Cf}\end{array}$ & $\begin{array}{l}7.50 \\
1.00 \\
\end{array}$ & $\begin{array}{l}7.38 \\
1.00 \\
\end{array}$ \\
\hline
\end{tabular}

The neutron energy spectra are from tables in the appendices of the report by Ing and Makra, ${ }^{16}$ unless noted otherwise.

See ref. 17.

'See ref. 33.

See ref. 24.

'See ref. 18. 
BLUE B-Y DOSIMETER

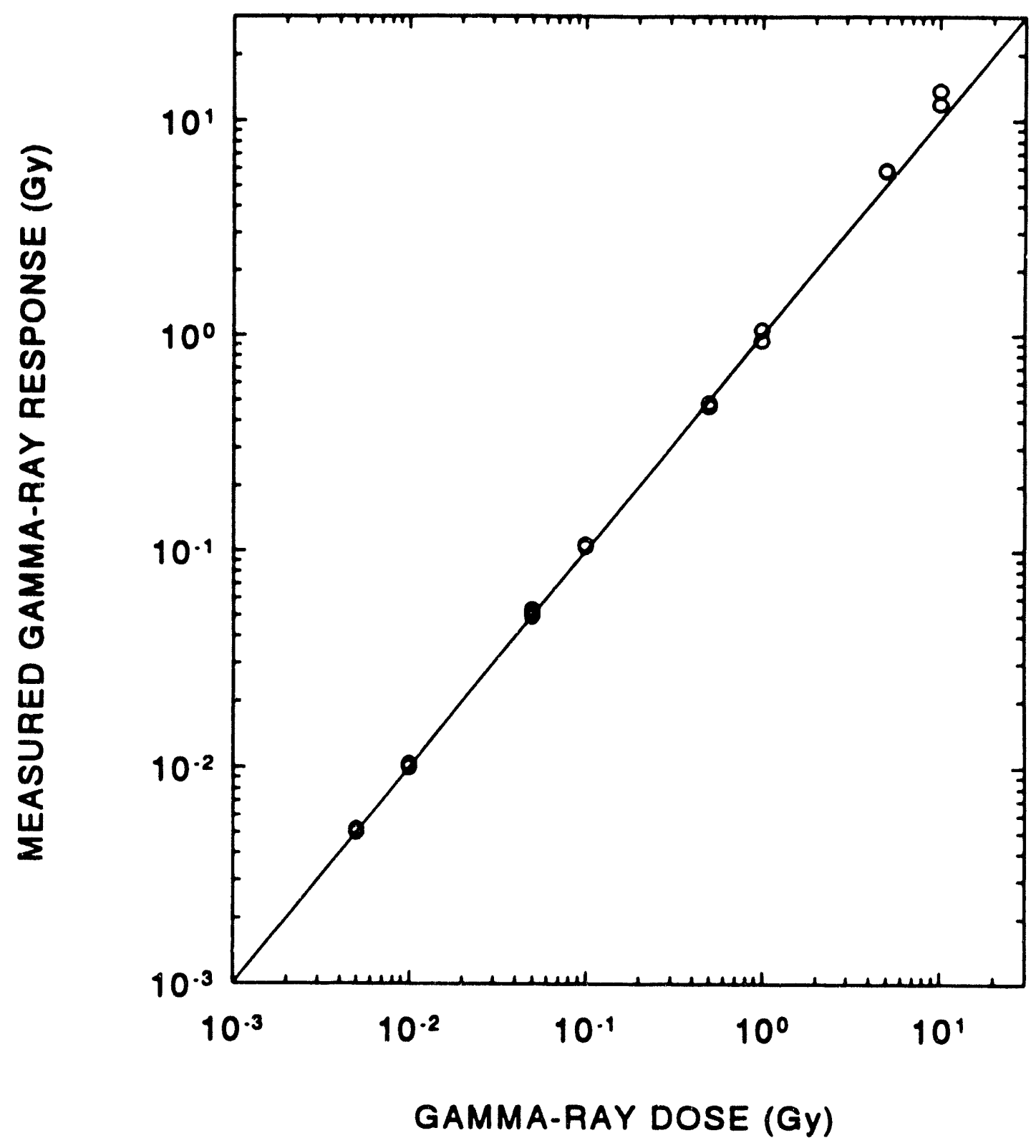

Fig. 17. Response of blue $\beta-\gamma$ dosimeter to high-level radiation from a ${ }^{137}$ Cs gamma-ray source. 
RED NEUTRON DOSIMETER

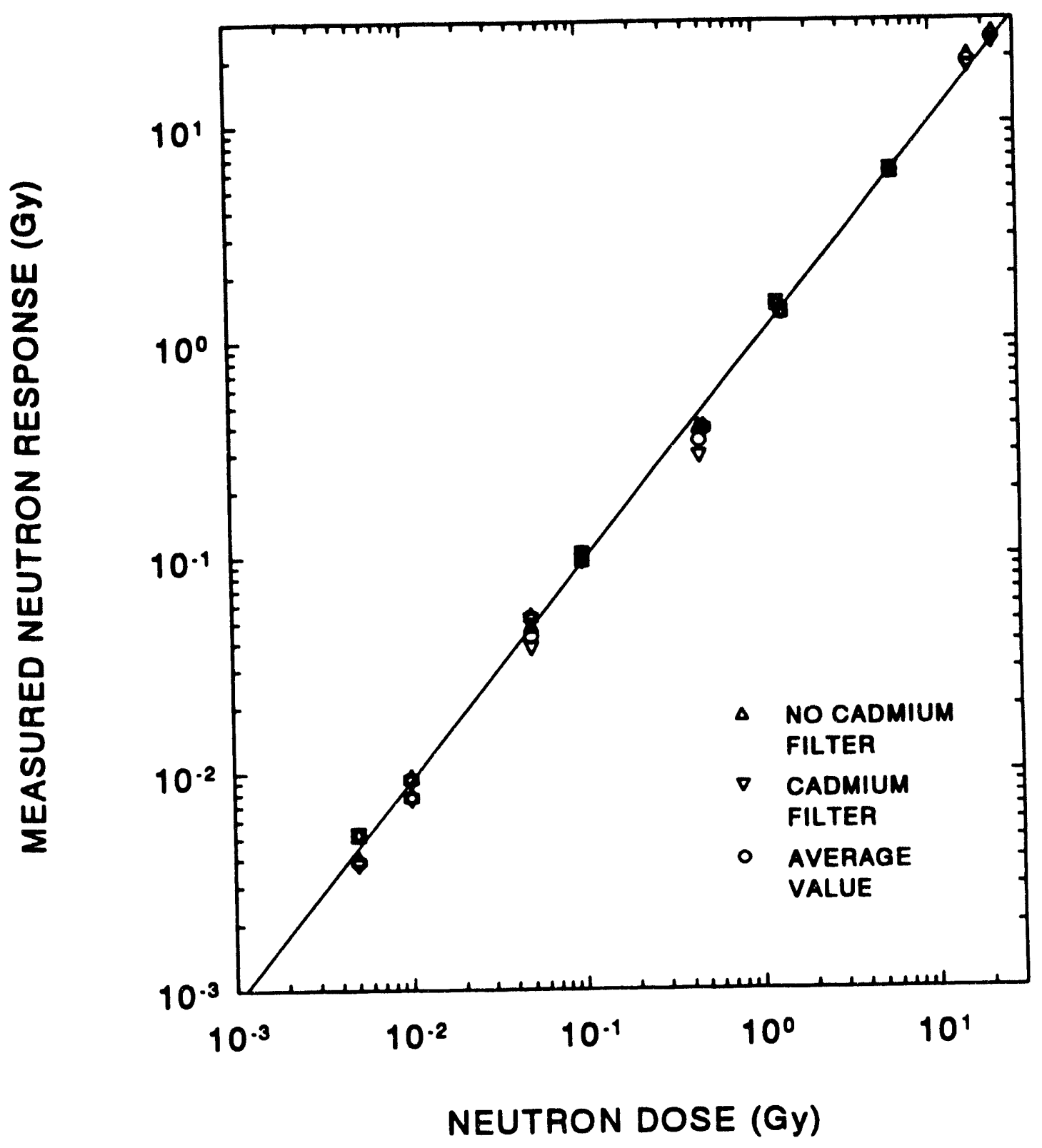

Fig. 18. Response of red neutron dosimeter to high-level radiation from $a^{222} \mathrm{Cr}$ neutron source with no shielding. 


\section{RED NEUTRON DOSIMETER}

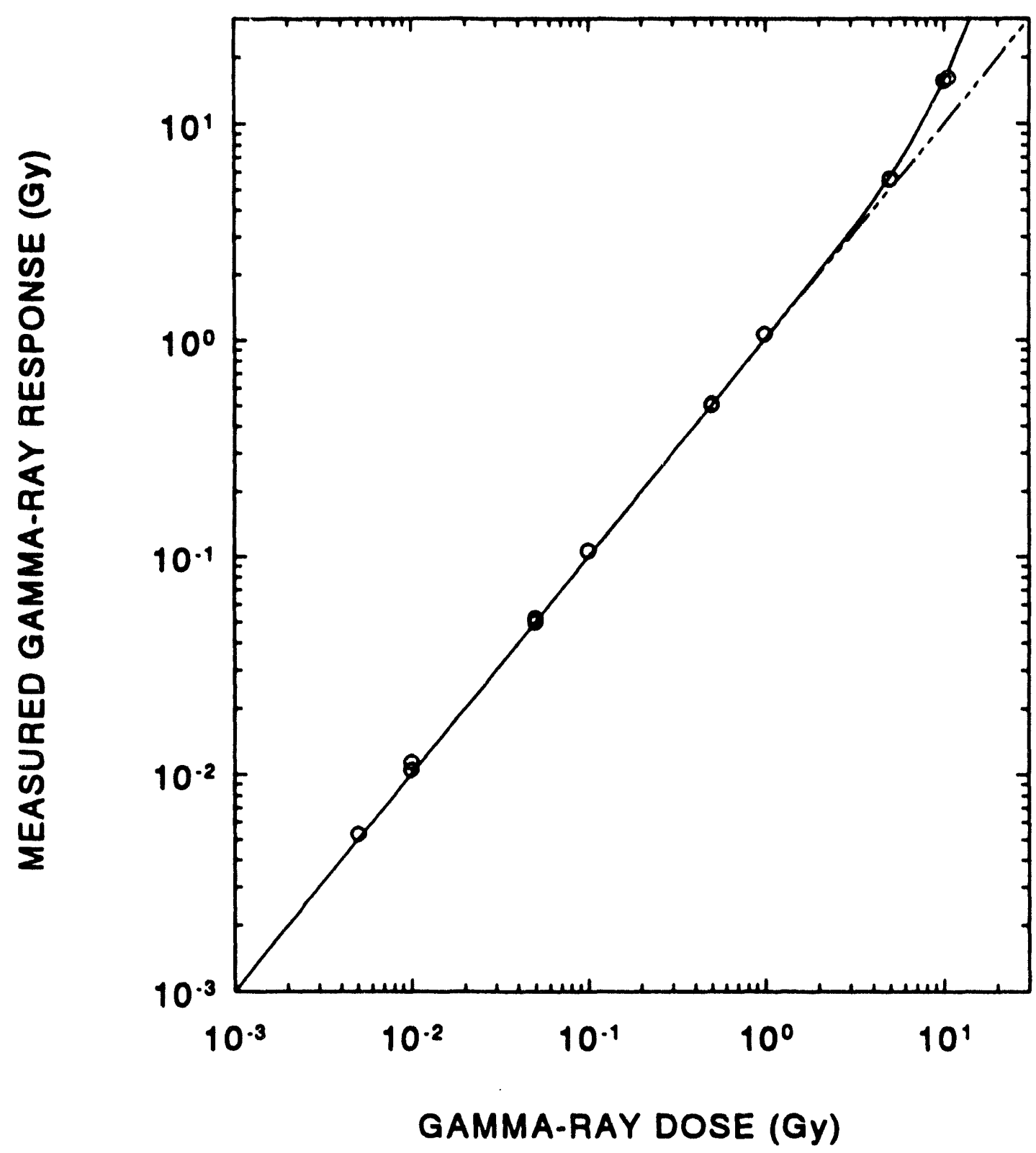

Fig. 19. Response of red neutron dosimeter to high-level radiation from a ${ }^{137}$ Cs gamma-ray source. The dashed line is for a linear response and the solid line shows a possible correction for supralinearity at the highest doses, near $10 \mathrm{~Gy}(1000 \mathrm{rad})$. The empirical power-fit equation for the solid line is $X+$ $\left(6 \times 10^{3}\right) X^{3}$, where $X$ is the gamma-ray dose in Gy. 
Two tests were conducted using the Aberdeen Reactor with the dosimeters positioned at distances of 1.7-16.4 $\mathrm{m}$ from the center of the reactor's core to obtain neutron doses ranging from approximately 0.1-10 Gy. The results are summarized in Tables 4 and 5 (ref. 27). The neutron doses at the dosimeter locations and the neutron spectra at several different distances were supplied by the Aberdeen Reactor facility. An attempt was made to analyze the data using these supplied neutron spectra, but they did not extend below $50 \mathrm{keV}$ in neutron energy where the dosimeters have their maximum sensitivity. To fill in the low-energy portion, (1) an unshielded HPRR spectrum was normalized to the neutron spectrum at $9 \mathrm{~m}$ from the Aberdeen Reactor, and (2) the low-energy portion of the HPRR spectrum was added to the Aberdeen Reactor spectrum at $9 \mathrm{~m}$ to obtain a more complete neutron-energy spectrum. This so-called combination HPRR and Aberdeen Reactor spectrum was then used to calculate the spectrum correction factors and the measured neutron responses for the dosimeters. An estimate of the additional neutron dose expected from the low-energy neutrons also resulted in a $6 \%$ correction to the neutron-dose values provided by the Aberdeen Reactor facility. The data presented in Tables 4 and 5 show that the dosimeters performed adequately with the exception of the measured neutron responses at the highest doses, near $10 \mathrm{~Gy}$ (1000 rad). One neutron dosimeter and three $\beta-\gamma$ dosimeters exceeded the $30 \%$ performance criterion for dose accuracy for neutrons in DUE Order 5480.11 (ref. 3). The overresponse at high doses can be attributed mostly to supralinearity of the TLD, but this does not take into account the uncertainty and error in the neutron-dose values provided by the Aberdeen Reactor facility. The minimum uncertainty is estimated to be at least 10\%, and the error offset may be larger (i.e., the errors are always positive and are offset on the average by about 15\%; see Tables 4 and 5). If the DOELAP method of evaluating dosimeters is used, then none of the dosimeters fail to respond within acceptade limits. ${ }^{35}$ Nevertheless, it should be noted that the dosimeters tended to have an overresponse rather than an underresponse, and, therefore, the dosimeters tended to error on the conservative side as is desirable. 
Table 4. Summary of the $\beta-\gamma$ doalmeter teats at the Aberdeen Reactor

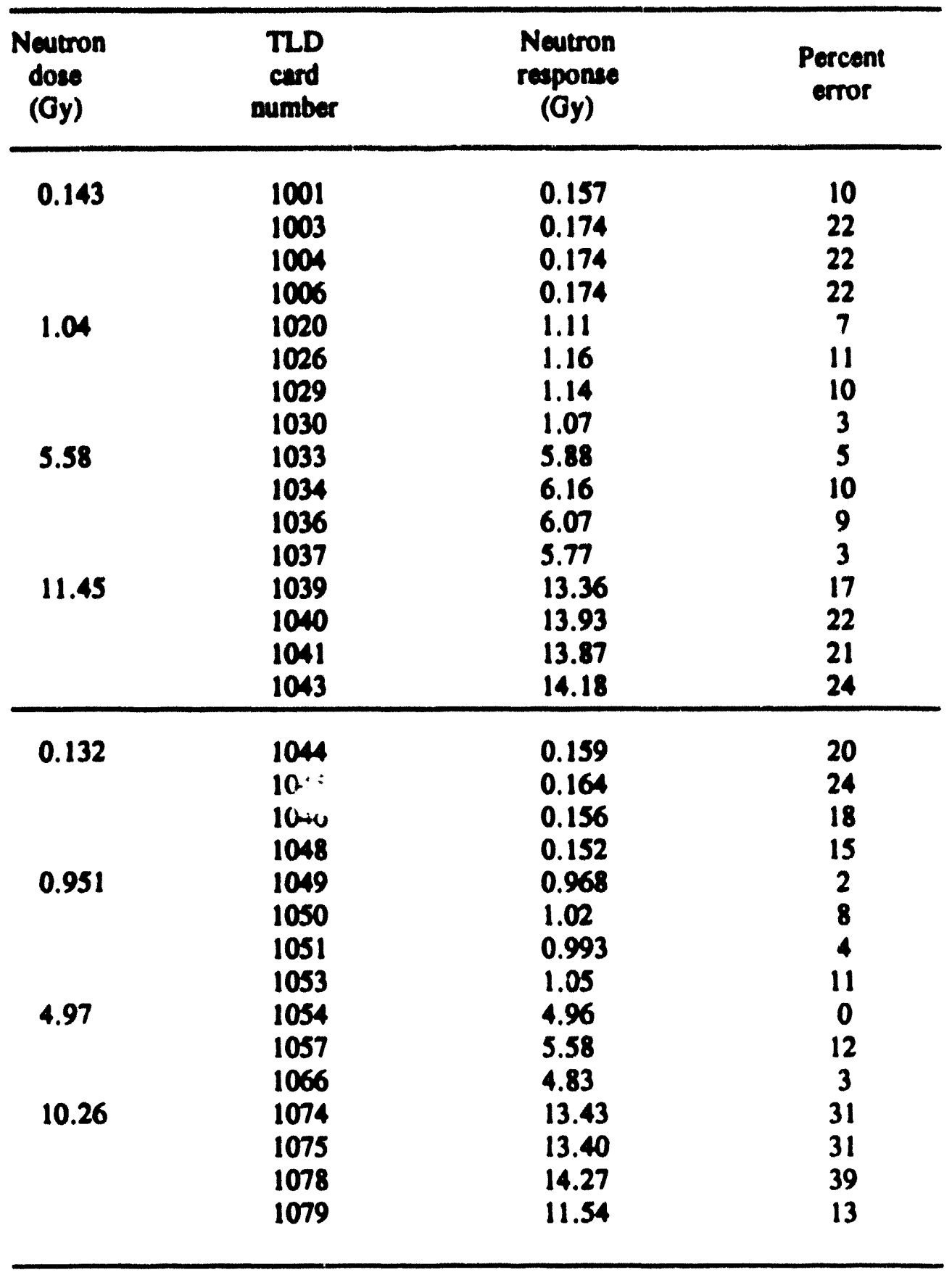


Table 5. Summary of neutron doalmeter teats at Aberdeen Reactor

\begin{tabular}{|c|c|c|c|c|c|}
\hline $\begin{array}{l}\text { Newron } \\
\text { dowe } \\
(n y)\end{array}$ & $\begin{array}{l}\text { TLD } \\
\text { enrd } \\
\text { number }\end{array}$ & $\begin{array}{l}\text { Cd-covered } \\
\text { repouse } \\
\left(O_{y}\right)\end{array}$ & $\begin{array}{l}\text { Dere } \\
\text { repones } \\
(O y)\end{array}$ & $\begin{array}{c}\text { Averase } \\
\text { reaponse } \\
(\mathrm{Oy})\end{array}$ & $\begin{array}{l}\text { Percen } \\
\text { error }\end{array}$ \\
\hline $\begin{array}{l}0.143 \\
1.04 \\
5.58 \\
11.45\end{array}$ & $\begin{array}{l}900001 \\
900002 \\
900007 \\
900015 \\
900016 \\
900017 \\
900019 \\
900020 \\
900021 \\
900024 \\
900026 \\
900028 \\
900034\end{array}$ & $\begin{array}{l}0.177 \\
0.173 \\
0.183 \\
0.169 \\
1.08 \\
1.26 \\
1.26 \\
1.15 \\
6.73 \\
6.77 \\
6.66 \\
6.39 \\
14.50\end{array}$ & $\begin{array}{l}0.170 \\
0.158 \\
0.174 \\
0.153 \\
1.00 \\
1.18 \\
1.13 \\
1.01 \\
5.85 \\
6.08 \\
6.15 \\
5.66 \\
1.260\end{array}$ & $\begin{array}{l}0.174 \\
0.165 \\
0.179 \\
0.161 \\
1.04 \\
1.22 \\
1.20 \\
1.08 \\
6.29 \\
6.42 \\
6.41 \\
6.03 \\
1.360\end{array}$ & $\begin{array}{c}22 \\
16 \\
25 \\
12 \\
0 \\
17 \\
15 \\
4 \\
13 \\
15 \\
15 \\
8 \\
19\end{array}$ \\
\hline 0.951 & $\begin{array}{l}900036 \\
900040 \\
900054 \\
900056 \\
900067 \\
900074 \\
900077 \\
900079 \\
900091 \\
900095 \\
900148 \\
900167 \\
900173 \\
900296 \\
900331 \\
900338\end{array}$ & $\begin{array}{l}0.154 \\
0.152 \\
0.156 \\
0.150 \\
1.04 \\
1.04 \\
1.09 \\
0.964 \\
5.80 \\
6.19 \\
5.70 \\
6.08 \\
13.40 \\
14.70 \\
13.20 \\
13.00\end{array}$ & $\begin{array}{l}0.144 \\
0.149 \\
0.153 \\
0.137 \\
0.961 \\
0.981 \\
1.02 \\
0.928 \\
5.29 \\
6.01 \\
5.54 \\
5.65 \\
12.60 \\
13.10 \\
12.00 \\
11.10\end{array}$ & $\begin{array}{l}0.149 \\
0.150 \\
0.154 \\
0.144 \\
1.00 \\
1.01 \\
1.06 \\
0.946 \\
5.54 \\
6.10 \\
5.62 \\
5.86 \\
13.00 \\
13.90 \\
12.60 \\
12.00\end{array}$ & $\begin{array}{c}13 \\
14 \\
17 \\
9 \\
5 \\
6 \\
11 \\
0 \\
12 \\
23 \\
13 \\
18 \\
26 \\
36 \\
23 \\
17\end{array}$ \\
\hline
\end{tabular}




\section{NUCLEAR ACCDENT DOSE ASSESSMENT}

The dose auseasment for a nuclear sccident can beat be illustraled by the use of datu from an ectual socident such as the one that occurred in 1962 at the 234.5 Building of Hanford's Recuplex Facility." When this sccident occurred, there were 22 persons inside the 234-5 Building and two guurds were stationed at a nearby gate house for a lotal of 24 employees. All of these employees were given a quick-son examination to determine who had been exposed to significant neutron radiation. Contamination surveys were also made, but no contumination was found. Three employees were identified as having received significant exposures to radiation during the sccident (these employees were designated as 11 . 117, and 123). 'nd the moat relevant data for use in our dosimetric inveatization have been summarized in Trove 6.

The perconnel dosimeters worn by the three employees indicated gamma-ray doses ranging from 0.13-0.63 Oy (13-63 rad). Two samples from each employee were also counted for sodium setivation. The firat sample congulated before it was counted, and the second sample was treated with heparin to prevent coagulation. The agreement between the two counts of blood sodium setivation is reasonably good, and they were simply avenaged together for use in our study. To convert the Hanford data on blood sodium ectivation from units of $\mu \mathrm{Ci}$ of ${ }^{2} \mathrm{Na}$ per $\mathrm{mL}$ of whole blood to Bq of ${ }^{2} \mathrm{Na}$ per gram of ${ }^{2 \mathrm{Na}}$, we used a value of $1.92 \mathrm{mg}$ of ${ }^{2} \mathrm{Na}$ per $\mathrm{mL}$ of whole blood, ${ }^{1011}$ and to convert Hanford data on hair sulfur activation from units of neutron per $\mathrm{cm}^{2}\left(\mathrm{n} \mathrm{cm}^{2}\right)$ to $\mathrm{Bq}$ of $2 \mathrm{p}$ per gram of hair, we used the Hanford values of $6.44 \times 10^{6} \mathrm{n} \mathrm{cm}^{-2}$ per dpm of "P per gram of sulfur and $47.7 \mathrm{mg}$ of sulfur per gram of hair."

The gamma-ray doses from the personnel dosimeters are used without correction because the hair sulfur activation and interviews of the employees suggest that they were primarily facing toward the source during their exposure periods. To estimate their neutron doses, we use the matios for the activation of hair to blood sodium from Table 6. These ratios suggest a factor of approximately $1.25 \times 10^{-4}$ for converting the specific activity of blood sodium (Bq of ${ }^{2} \mathrm{Na}$ per gram of ${ }^{23} \mathrm{Na}$ ) to absorbed dose (Gy) from neutrons (sec Tables 1 and 2 and Figs. 8-12 of this report). The neutron doses obtained in our dose-assessment study are about twice those given in the Hanford report. ${ }^{24}$ In spite of the differences, the agreement is considered reasonably good. The Hanford neutron doses are so-called first-collision doses in a small tissue equivalent detector in air (which is now commonly referred to as kerma in tissue free-in-air), and our neutron dose estimates are so-called multicollision doses at the surface of the body facing loward the source. 
Table 6. Dodmatite Lavedigation of the Recuplex ertikallty aceldent

Percoened dostencter:
Oemenany does (Oy)
0.63
0.23
0.13

Blood sodtum scativedion

(Bq of "Nd/8 of $\left.{ }^{2} \mathrm{Na}\right)$ :

\section{Semple of \\ Semple 12 \\ Man velue}

$2.89 \times 10^{0}$

$3.47 \times 10^{\circ}$

$3.18 \times 10^{\circ}$
$1.70 \times 10^{\circ}$

$1.41 \times 10^{\circ}$

$1.56 \times 10^{4}$
$3.85 \times 10$

$4.05 \times 10^{2}$

$3.95 \times 10$

Hale sulfur scatretioa (Bq of DP/le of halr):

$$
\begin{aligned}
& \text { Top of beed } \\
& \text { Cuen } \\
& \text { Puble } \\
& \text { Bact } \\
& \text { Les }
\end{aligned}
$$

Retio for cativetion of buls to blood codluar (unitlans):

Abeorted does a eurfice of body fectes lowerd source:

$$
\begin{aligned}
& \text { Oammon rays (Oy) } \\
& \text { Nowront (Oy) } \\
& \text { Towl (Oy) }
\end{aligned}
$$

$$
\begin{aligned}
& 2.96 \times 10^{1} \\
& 3.58 \times 10^{1} \\
& 2.22 \times 10^{1} \\
& 1.25 \times 10^{1}
\end{aligned}
$$

$5.31 \times 10^{2}$

$1.73 \times 10^{1}$

$9.51 \times 10^{2}$

$1.12 \times 10^{1}$

$4.69 \times 10^{2}$

$1.13 \times 10^{-9}$

$1.11 \times 10^{4}$

$1.34 \times 10^{4}$ otherwise.

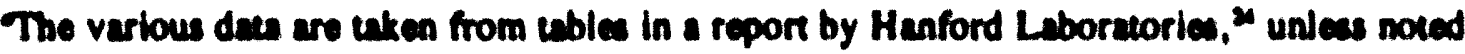

Two sumples were couneed for ach employes: the firse ample had congulated before it was counted, and the second ample wee treated with heparin to prevent coagulation.

The ratios were calculaned in this study using the largent value for halr sulfur setivation divided by the man value of Samplen $\| 1$ and $n$ for blood sodium activation.

The gamma-ray doses from the personnal dosimecers were used without correction because the hair sulfur activation and interviows of the employen sugecut they were primarily facing coward the source during their exposure period.

The ratos for activation of halr to blood sodium susseat a factor of approximately $1.25 \times 10^{-1}$ for converting the specinc setivity of blood sodium (Bq of ${ }^{2} \mathrm{Na}$ per 8 of ${ }^{2} \mathrm{Na}$ ) 10 sbeorbed dose (Gy) from neutrons (see Tables 1 and 2 and Figs. 8-12 of this report). 


\section{CONCLUSIONS}

The ORNL NAD syetem is capable of providing doce information down to about 0.01 Oy (1 nd) within $24 \mathrm{~h}$. The erron involved in the evaluation of the dose that a person received in - nuclear cocident can be significant due 10: (1) unknowns in the determination of the configuration of the nealle material in the socident assembly; and (2) lack of complete informution concerning the location, ortentation, and posable shielding of the person at the time of the cocident. The PNAD unit is detigned to provide information on the absorbed dose at the surfuce of the body fecing the source. Body attenuntion has the effect of reducing the gamma. ny dow by a fector of about 2 and the neutron dose by a fector of about 10 at a personnel dodimeter worn on the fis side of the body from the source. If data are avaliable from area dodmeter unit, then it is necesury to recognize that the extimated gamma-nay dose from the perconnel dosimeter may noed to be muldiplied by a fector of a much as 2, and the eatimated neutron dowe by a factor of as much a 10 (ref. 2). Thus, the setivation of sodium in blood and sulfur in hair will be used in conjunction with the detectors from both PNAD and FNAD units to improve the absorted dose eedimates for individuals involved in the socident. 


\section{RrFinanCEs}

1. Amertcan Nartonal Standard: Dastmerny fo Critcally Accidents, ANSI Repon N13.3-1969, American Nediond Standards Institute, New York, 1969.

2. Dastmerny for Critically Acetdents: A Manual, Technical Repon Series 211, Int. Atomic Energy Agency, Vienna, 1982.

3. Radiartion Provection for Occupartional Wonters, DOE Order 5480.11, U.S. Department of Enerzy, Washington, D.C., 1988.

4. R. H. Mole, "Sodium in Man and the Ascosument of Rediation Dose Anter Critical Accidents," Phys. Med. Blol. 29, 1307-1327, 1924.

5. M. T. Ryen e. al. Callbration of the Indiwn Foll Used for Critcalliry Aceldent Dasimerry in the UCC-MD Bmployee Idenvificaston Badge, ORNLTM-8294, Martin Marieta Enerey Systems, Inc., Ouk Ridge Nall. Lab., Onk Ridge, Tenneasec, May 1982.

6. R. B. Swaja and R. Oyan, "Uncertuindies Ascociabed with Using Quick-Sor Techniques to Endimate Neutron Doses Following Criticality Accidents," Healch Phys. 52, 65-68, 1987.

7. W. H. Caceon, Sr., personal communication to O. T. Mel, Oak Ridge Nat. Lab., December 1991.

8. H. J. Delafield, "Nuclear Accident Dosimetry," Radiar. Prot. Dasim. 10, 237-249, 1985.

9. W. S. Snyder $\alpha$. a., Repor of the Task Group on Reference Man, Publication 23. Intenternational Commission on Radiological Protection, Pereamon Press, Oxford, 1981.

10. W. O. Cross and H. Ing. "Sodium Activation in the Human Body," Radias. Prot. Dasim. 10, 265-276, 1985.

11. Z. Ubovic and I. Miric, "Blood-Sodium Measurements for Nuclear Accident Dosimetry." Pp. 153-164, in Advances in Radiarion Protection Monitoring, IAEA-SM-229/49, Int. Alomic Enerzy Agency, Vienna, 1979.

12. N. W. Teitz, ed., Texsboak of Clinical Chemistry, W. B. Sanders Co., Philadelphia, 1986.

13. D. A. Weber et. al., MIRD: Radionuclide Dava and Decay Schemes, The Society of Nuclear Medicine, New York, 1989.

14. Y. Feng a. a., Deserminarion of Neurron Dase from Criticaliny Accidents with Bioassays for ${ }^{2} \mathrm{Na}$ in Bload and ${ }^{2 P}$ in Hair, ORNLTM-12028, Martin Marietta Energy Systems, Inc., Oak Ridge Natl. Lab., June 1993. 
15. W. O. Croas, "Neutron Activation of Sodium in Phantoms and the Human Body," Health Phys. 8, 371-379, 1981.

16. H. Ins and S. Malon, Compendlun of Newron Spectra in Crificallin Accident Dasimerry, Technical Report Seriea 180, Int. Atomic Energy Agency, Vienna, 1978.

17. C. S. Sims and O. E. Ragen, Healch Physics Research Reactor Reference Dosimerry, ORNL-6240, Martin Marietta Energy Systems, Inc., Oak Ridge Natl. Lab., Oak Ridge. Tenneaver, June 1987.

18. Newron Reference Radlations for Callbrating Newron-Measuring Devices Used for Radiartion Provection Pupases and for Determining cheir Response as a Function of Neurron Enervy, Repon 8529-1989, Internutional Orzanization for Standandization, Ceneva, 1989.

19. J. A. Auxier, W. S. Snyder, and T. D. Jones, "Neutron Interactions and Penetration in Tisure," pp. 275-316, in Radlation Dosimetry, Vol. 1, d. F. H. Attix and W. C. Roesch, Academic Preas, New York, 1968.

20. D. F. Petercon, V. B. Mitchell, and W. H. Langham, "Estimation of Fust Neutron Doses in Man by "S(n,p) and "p Reaction in Body Hair," Health Phys. 6, 1-5, 1961.

21. D. E. Hankins, "Direct Counting of Hair Samples for "2p Activation," Healeh Phys. 17, $740742,1969$.

22. T. Takeuchi at. al. "Survey of Trace Elements in Hair of Normal Japanese," pp. 545-561, in Nuclear Activation Tectniques in the Life Sciences 1978, Int. Atomic Energy Agency, Vienna, 1979.

23. W. H. Buckalew and K. C. Humpherys, "Threshold Detectors," pp. 58-68, in Experimental Reactor Anatysis and Radiation Measurements, od. D. O. Glower, McOnw-Hill, New York, 1965.

24. Hanford Laboratories, "Dosimetry Inveatigation of the Recuplex Criticality Accident," Health Pthys. 9, 757-768, 1963.

25. B. A. Magumo, R. R. Kinsey, and F. M. Scheffel, Guideboak for the ENDF/B-V Nuclear Dala Flles, NP-2510, Brookhaven Nall. Lab., Brookhaven, N.Y., 1982.

26. D. E. Hankins, Dosimetry of Criticality Accidents Using Activations of the Blood and Hair," Healeh Phys. 38, 529-541, 1980.

27. G. T. Mei and W. H. Casson, Sr., Cenuralized Exremal Dosimerry System (CEDS) Nuclear Accident Dosimeter, CEDS Technical Report No. 91-3, Martin Marietta Energy Systems, Inc., March 1991. 
28. J. F. Fowler and F. H. Attix, "Solid State Integrating Dosimeters," pp. 241-290, in Radiartion Dasimerny, Vol. 1, ed. F. H. Attix and W. C. Roesch, Acadeinic Press, New York, 1966.

29. J. C. LuU, C. S. Sims, and J. C. Poston, The Developmens, Characierization, and Performance Eualuation of a New Combination Type Personnel Neuron Dosimeter. ORNL-6593, Martin Marietu Energy Systems, Inc., Ouk Ridge NaUl. Lab., October 1989.

30. Techuical Basis for the Cenuralized Extemal Dasimetry System. Centralized External Dodimetry System, Martin Marietta Energy Systems, Inc., Seplember 1991.

31. R. W. Enz and H. M. Murphy, "Gumma Ray Dose in a Cylindrical Phantom," Health Phys. 24, 53-58, 1973.

32. R. V. Oriffith a. a.. "Recent Developments in Personnel Neutron Dosimeters," Health Phys. 36, 235-260, 1979.

33. H. Ing a. a., To Determine the Neurron Leakage Spectrum from the Crtical Facillin at Abendeen Proving Grounds, Maryland, BTT-89/3-30, Bubble Technology Industries, Chalk River, Onturio, 1989.

34. W. H. Cascon, Sr., personal communication to G. T. Mei, Oak Ridge Natl. Lab., January 1991.

35. Department of Energy Laboratory Accredicasion Program for Personnel Dosimetry, DOE Order 5480.15, U.S. Department of Energy, Washington, D.C., 1987. 
ORNL/TMi-12224

\section{INTERNAL DISTRIBUTION}

1. J. F. Alexander

2. B. A. Berven

3. R. S. Bogard

4. W. H. Casson

5. M. Cristy

6. S. W. Croslin

7. E. C. Crume

8. W. L. DeRossett

9. K. F. Eckerman

10. R. J. Forbes

11. C. M. Hopper

12. J. B. Hunt

13-17. G. D. Kerr

18. C. E. Maples

19-23. G. T. Mei
24. R. L. Mlekodaj

25. G. L. Murphy

26. W. F. Ohnesorge

27. P. S. Rohwer

28. J. C. Ryman

29. C. S. Sims

30. R. E. Swaja

31. J. H. Swanks

32-34. M. Thein

35. Central Research Library

36. ORNL Technical Library, Y-12

37-38. Laboratory Records Department

39. Laboratory Records-RC

40. ORNL Patent Section

\section{EXTERNAL DISTRIBUTION}

41. Office of Assistant Manager for Energy Research and Development, Department of Energy, Oak Ridge Operations Office, P.O. Box 2001, Oak Ridge, TN 37831-8600

42-43. Office of Scientific and Technical Information, P.O. Box 62, Oak Ridge, TN 37831

44. A. Bassett, Department of Energy, Oak Ridge National Laboratory, P.O. Box. 2008, Oak Ridge, TN 37831-6269

45. K. W. Crase, Westinghouse Savannah River Co., Savannah River Site, Bldg. 735A, Aiken, SC 29802

46. H. H. Hsu, Los Alamos National Laboratory, P.O. Box 1663, MS-G761, Los Alamos, NM 87545

47. L. F. Miller, University of Tennessee, Department of Nuclear Engineering, Knoxville, TN 37996

48. J. W. Poston, Texas A\&M University, Department of Nuclear Engineering, College Station, TX 77843

49. R. B. Schwartz, National Institute of Standards and Technology, Bldg. 235, Gaithersurg, MD 20899

50. G. G. Simons, Engineering Experiment Station, Durland Hall, Kansas State University, Manhattan, KS 66506-5103 

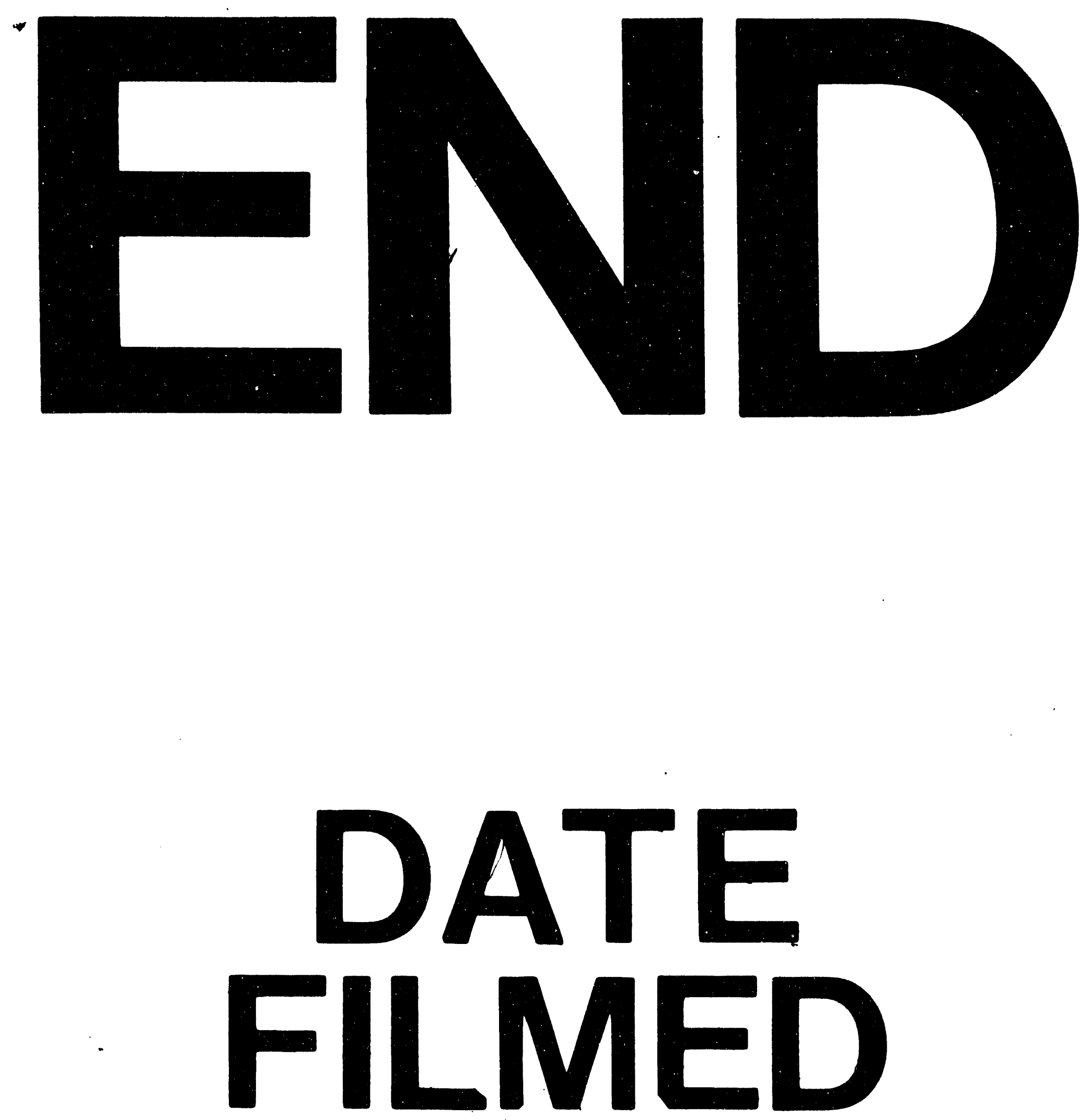

I

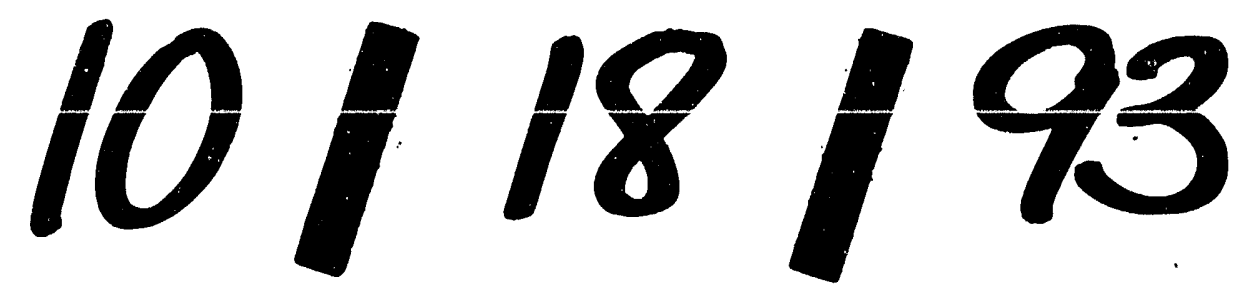


